\title{
Thyroid hormones in fetal growth and prepartum maturation
}

\section{A J Forhead ${ }^{1,2}$ and A L Fowden ${ }^{1}$}

${ }^{1}$ Department of Physiology, Development and Neuroscience, University of Cambridge, Physiology Building, Downing Street, Cambridge CB2 3EG, UK

${ }^{2}$ Department of Biological and Medical Sciences, Oxford Brookes University, Oxford OX3 OBP, UK
Correspondence should be addressed to A L Fowden Email alf1000@cam.ac.uk

\begin{abstract}
The thyroid hormones, thyroxine $\left(T_{4}\right)$ and triiodothyronine $\left(T_{3}\right)$, are essential for normal growth and development of the fetus. Their bioavailability in utero depends on development of the fetal hypothalamic-pituitary-thyroid gland axis and the abundance of thyroid hormone transporters and deiodinases that influence tissue levels of bioactive hormone. Fetal $\mathrm{T}_{4}$ and $\mathrm{T}_{3}$ concentrations are also affected by gestational age, nutritional and endocrine conditions in utero, and placental permeability to maternal thyroid hormones, which varies among species with placental morphology. Thyroid hormones are required for the general accretion of fetal mass and to trigger discrete developmental events in the fetal brain and somatic tissues from early in gestation. They also promote terminal differentiation of fetal tissues closer to term and are important in mediating the prepartum maturational effects of the glucocorticoids that ensure neonatal viability. Thyroid hormones act directly through anabolic effects on fetal metabolism and the stimulation of fetal oxygen consumption. They also act indirectly by controlling the bioavailability and effectiveness of other hormones and growth factors that influence fetal development such as the catecholamines and insulin-like growth factors (IGFs). By regulating tissue accretion and differentiation near term, fetal thyroid hormones ensure activation of physiological processes essential for survival at birth such as pulmonary gas exchange, thermogenesis, hepatic glucogenesis, and cardiac adaptations. This review examines the developmental control of fetal $\mathrm{T}_{4}$ and $\mathrm{T}_{3}$ bioavailability and discusses the role of these hormones in fetal growth and development with particular emphasis on maturation of somatic tissues critical for survival immediately at birth.
\end{abstract}

Key Words

- thyroid hormones
- intrauterine growth

- maturation

- neonatal adaptation
Journal of Endocrinology (2014) 221, R87-R103

\section{Introduction}

The thyroid hormones, thyroxine $\left(\mathrm{T}_{4}\right)$ and triiodothyronine $\left(\mathrm{T}_{3}\right)$, are detectable in the fetal circulation from early in gestation and have important developmental, metabolic, and maturational effects in the fetus in all species studied to date including human infants. Their bioavailability in fetal plasma and tissues is regulated developmentally and also varies with species, gestational age, availability of nutrients and oxygen, and the endocrine environment in utero (Fowden \& Forhead 2009, 2013). Deficiency of thyroid hormones during intrauterine development impairs growth of the fetus and compromises its adaptation to extrauterine life (Fowden et al. 1998, Hillman et al. 2012, Sferruzzi-Perri et al. 2013). Conversely, fetal administration of thyroid hormones can promote tissue differentiation and activation of many of the physiological processes that have little or no function 
before birth but which are essential for neonatal survival (Fowden et al. 1998). This review examines the developmental control of fetal $\mathrm{T}_{4}$ and $\mathrm{T}_{3}$ bioavailability and discusses the role of these hormones in fetal growth and development with particular emphasis on the maturation of somatic tissues essential for survival immediately at birth. The important role of thyroid hormones in brain development is not considered here as this has been reviewed extensively in recent years (Horn \& Heuer 2010, Patel et al. 2011, Puig-Domingo \& Vila 2013, Stenzel \& Huttner 2013).

\section{Bioavailability of thyroid hormones before birth}

In fetal and adult animals, the bioavailability of thyroidstimulating hormone (TSH) and the two biologically active thyroid hormones, $T_{4}$ and $T_{3}$, is determined by several factors: i) the activity of the hypothalamic- pituitary-thyroid axis and production of $\mathrm{T}_{4}$ and $\mathrm{T}_{3}$, ii) the peripheral conversion of $\mathrm{T}_{4}$ to more biologically active $\mathrm{T}_{3}$ or to inactive metabolites to vary circulating and tissue-specific concentrations, and iii) the uptake of thyroid hormones into target tissues and activation of cellular processes by binding to thyroid hormone receptors (TRs; Fig. 1). Before birth, all of these factors show developmental and tissue-specific regulation. In addition, placental transfer of thyroid hormones from the mother can contribute to the concentration of thyroid hormones in the fetal circulation, depending on the species and placental type (Fig. 1).

\section{Activity of the fetal hypothalamic-pituitary-thyroid axis}

The thyroid gland originates as an outgrowth from the developing pharyngeal floor in the early embryo and undergoes three main stages of growth and differentiation: pre-colloid, colloid, and follicular (Brown 2004,

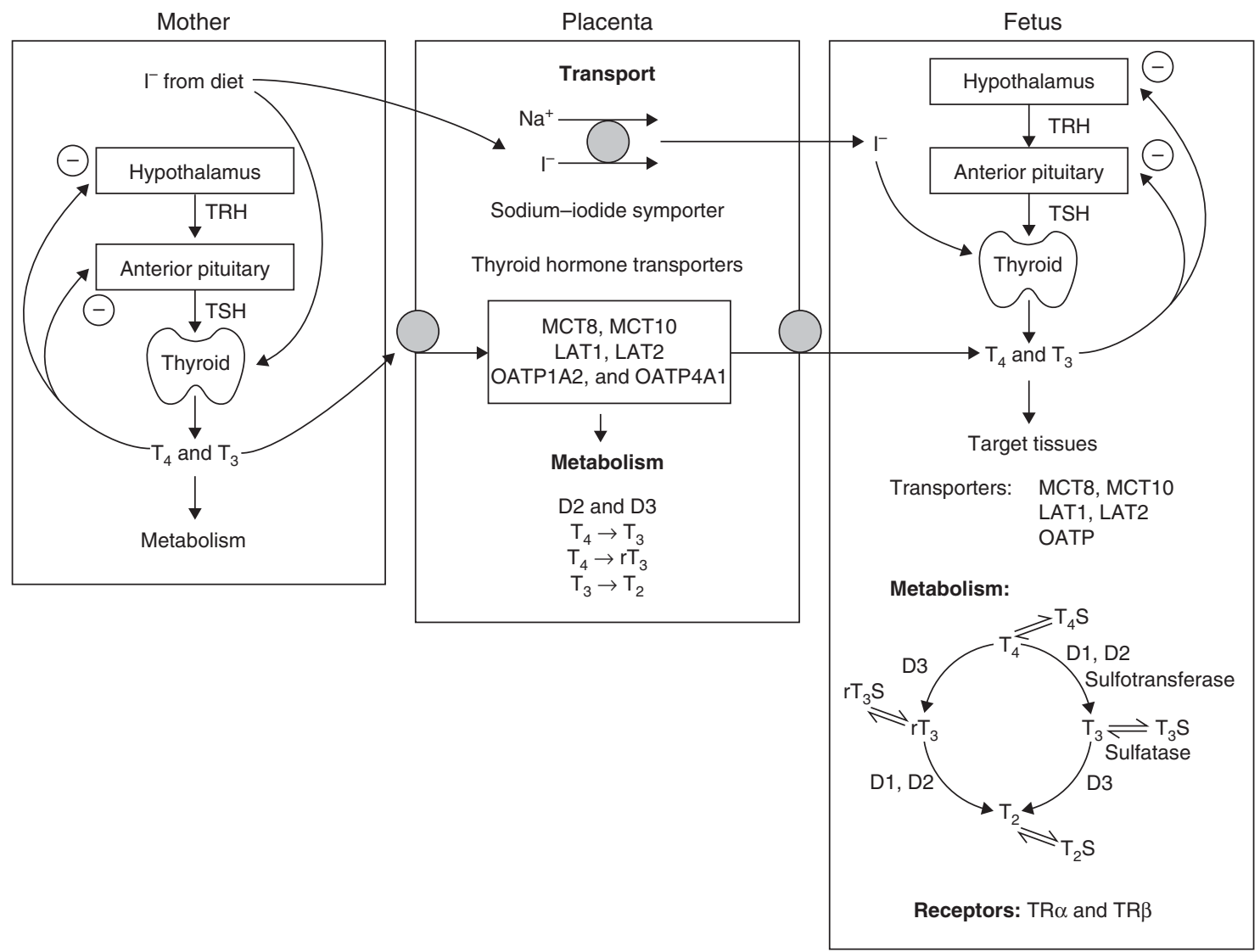

Figure 1

Schematic diagram showing the factors affecting the bioavailability of thyroid hormones in the fetus, placenta, and mother. TRH, thyrotropinreleasing hormone; $\mathrm{TSH}$, thyroid-stimulating hormone; $\mathrm{T}_{4}$, thyroxine; $T_{3}$, triiodothyronine; $r T_{3}$, reverse $T_{3} ; T_{2}$, diiodothyronine; $S$, sulfated;
D1, D2, and D3, deiodinases; OATP, organic anion transporters; LAT1 and LAT2, L-type amino acid transporters 1 and 2; MCT8 and MCT10, monocarboxylate transporters 8 and 10 . http://joe.endocrinology-journals.org DOI: 10.1530/JOE-14-0025
(C) 2014 Society for Endocrinology Printed in Great Britain 
Santisteban 2013). The follicular structural development of the thyroid gland coincides with the functional development of the hypothalamic-pituitary-thyroid axis and the secretion of thyroid hormones into the fetal circulation (Table 1). Hypothalamic neurones produce thyrotropin-releasing hormone (TRH), which stimulates the thyrotropes of the anterior pituitary gland to secrete TSH. In turn, TSH acts on the thyroid gland to promote follicular growth and stimulate the synthesis and secretion of the thyroid hormones. In the human fetus sampled by cordocentesis, serum concentrations of TSH and free and total $\mathrm{T}_{4}$ increase from mid-gestation with an exponential rise in free $\mathrm{T}_{3}$ closer to term (Thorpe-Beeston et al. 1991a). In fetal life, as in adult life, the thyroid hormones control their own production by negative feedback effects on the hypothalamus and pituitary, at least by late gestation, although the axis continues to mature in sensitivity postnatally (Hopkins et al. 1975, Polk et al. 1991, Rakover et al. 1999, Hernandez et al. 2006). Normal production of thyroid hormones by the fetal thyroid gland depends upon iodide uptake by the follicular cells of the gland and iodide is actively transported from the maternal circulation across the placenta (Fig. 1).

The pattern of thyroid gland development and thyroid hormone activity is comparable in all mammals studied, but the timing of the developmental stages can vary between species. Table 1 compares the ontogeny of aspects of thyroid hormone activity in human, sheep, and rats. These include development of the hypothalamicpituitary-thyroid axis, onset of thyroid hormone production, and expression of TRs. Overall, human and ovine fetuses are similar in the timing, relative to gestational age, of the structural development of the thyroid gland and the onset of thyroid hormone activity, while rodent species show relatively delayed maturation of thyroid hormone bioavailability (Table 1; Fisher \& Polk 1989, Polk 1995). From mid-gestation in human and ovine fetuses, the thyroid gland secretes $\mathrm{T}_{4}$ and $\mathrm{T}_{3}$ under the control of the hypothalamic-pituitary axis and the thyroid hormone axis is fully functional around the time of birth (Table 1). In rats, however, maturation of thyroid hormone activity continues up to 4 weeks of postnatal life (Table 1).

\section{Metabolism of thyroid hormones in utero}

The circulating concentrations of the thyroid hormones are controlled, not only by the output of the thyroid gland, but also by metabolism in peripheral tissues (Fig. 1). In the fetus, thyroid hormones can undergo deiodination and sulfation to more or less active metabolites. The metabolism of $\mathrm{T}_{4}$ into more genomically potent $\mathrm{T}_{3}$ or relatively bio-inactive reverse $\mathrm{T}_{3}\left(\mathrm{rT}_{3}\right)$ depends on the activity of deiodinase enzymes, which are developmentally regulated in specific tissues (Brent 2012,

Table 1 Comparison of the timing of developmental stages of thyroid hormone bioavailability among human, sheep, and rat fetuses. Data adapted from Thorburn \& Hopkins (1973), Bernal \& Pekonen (1984), Perez-Castillo et al. (1985), Ferreiro et al. (1987), Polk et al. (1989, 1991), Thorpe-Beeston et al. (1991b), Polk (1995), Brown (2004), and Chan et al. (2011)

\begin{tabular}{l} 
Developmental stage \\
\hline Gestational age at term \\
Thyroid gland organogenesis \\
Pre-colloid \\
Colloid \\
Follicular \\
TRH in hypothalamus \\
TSH in anterior pituitary gland \\
and circulation \\
TSH receptor in thyroid gland \\
lodide uptake in thyroid gland \\
Thyroglobulin synthesis \\
lodinated amino acids \\
Synthesis and secretion of thyroid \\
hormones \\
Rise in plasma $T_{3}$ \\
Gene and protein expression of \\
thyroid hormone transporters \\
Thyroid hormone receptor binding
\end{tabular}

\begin{tabular}{l} 
Human (weeks) \\
\hline 40 \\
$7-13(0.18-0.33 \mathrm{G})$ \\
$13-14(0.33-0.35 \mathrm{G})$ \\
$>14(>0.35 \mathrm{G})$ \\
$10-12(0.25-0.30 \mathrm{G})$ \\
$10-12$ \\
$10-12$ \\
$10-12$ \\
$10-12$ \\
$14(0.35 \mathrm{G})$ \\
$16-18(0.40-0.45 \mathrm{G})$ \\
30 weeks to birth \\
$7-9(0.18-0.23 \mathrm{G})$ cerebral cortex \\
$10-16$ (0.25-0.40G) brain, heart, \\
liver, and lung
\end{tabular}

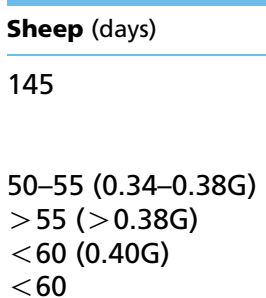

$50(0.34 G)$

$70(0.48 \mathrm{G})$

60-70 (0.40-0.48G)

135 days to birth
$<50$ (0.34G) brain, liver, and lung

\section{Rat (days)}

21

\section{$17(0.81 \mathrm{G})$}

18 days -3 weeks postnatally $16(0.76 \mathrm{G})$

$17(0.81 \mathrm{G})$

$15(0.71 G)$

15

$17(0.81 \mathrm{G})$

$17.5(0.83 \mathrm{G})$

Birth to 3 weeks postnatally

\author{
14-16 (0.67-0.76G) brain, \\ heart, liver, and lung
}

Percentage of total gestation (G) are given in brackets.

http://joe.endocrinology-journals.org DOI: 10.1530/JOE-14-0025 (c) 2014 Society for Endocrinology Printed in Great Britain
Published by Bioscientifica Ltd. 
Chi et al. 2013). Three key deiodinase enzymes are found in both fetal and adult tissues: D1, D2, and D3 (Bianco et al. 2002). D1 is primarily a $5^{\prime}$-monodeiodinase enzyme that catalyzes outer-ring deiodination of $\mathrm{T}_{4}$ to $\mathrm{T}_{3}$ and of $\mathrm{rT}_{3}$ to $\mathrm{T}_{2}$. This enzyme is present in the fetal liver, kidney, and thyroid and pituitary gland, and the production of $\mathrm{T}_{3}$ by hepatic D1 is considered to be the major endocrine source of circulating $\mathrm{T}_{3}$ concentrations (Polk 1995). D2 is also a 5'-deiodinase enzyme with kinetic characteristics different from D1 that is found primarily in the brain, pituitary gland, placenta, and brown adipose tissue. In these tissues, D2 generates local concentrations of $\mathrm{T}_{3}$ that are essential for normal tissue development and function, rather than contributing significantly to the circulating pool of $\mathrm{T}_{3}$. D3 is a $5^{\prime}$-monodeiodinase enzyme that catalyzes inner-ring deiodination of $\mathrm{T}_{4}$ to transcriptionally inactive $\mathrm{rT}_{3}$, and of $\mathrm{T}_{3}$ to inactive $\mathrm{T}_{2}$. This enzyme is present in the liver, kidney, and skin and is highly expressed in the uterus, placenta, and amniotic membrane, where it has an important role in the clearance of circulating thyroid hormones and in regulating placental transfer of maternal thyroid hormones to the fetus. Therefore, as an enzymatic barrier, placental D3 limits the exposure of the fetus to maternal thyroid hormones. In the human placenta, the enzyme activity, and mRNA and protein expression, of D2 are greatest in the first trimester compared with term, but significantly lower than those of D3 at all gestational ages studied (Koopdonk-Kool et al. 1996, Chan et al. 2003). These findings suggest that local production of $\mathrm{T}_{3}$ may be important for early placental development, but is unlikely to contribute significantly to circulating $\mathrm{T}_{3}$ concentrations in the fetus.

The Dio3 gene that encodes D3 has been shown to be imprinted in the mouse and is preferentially expressed by the paternal allele (Hernandez et al. 2002, Tsai et al. 2002). However, imprinting does not occur in all fetal tissues and, where it does, expression from the paternal allele varies from $75-85 \%$ in fetal tissues to $50-60 \%$ of total expression in the placenta (Charalambous \& Hernandez 2013). Knockout of the Dio3 gene causes perinatal thyrotoxicity and partial lethality at or before birth (Hernandez et al. 2006). Birth weight is normal in the live mutant pups but there are abnormalities in the pancreatic $\beta$-cells, retina, and hypothalamus at birth with a more severe growthrestricted phenotype developing with increasing postnatal age (Hernandez et al. 2006, Ng et al. 2010, Medina et al. 2011, Ueta et al. 2012). The tissue-specific patterns of imprinting and expression of Dio3 suggest that this deiodinase has both paracrine and endocrine actions in preventing feto-placental over exposure to thyroid hormones at critical stages of development.

Another important pathway in thyroid hormone metabolism in utero is sulfation, whereby around $80 \%$ of $\mathrm{T}_{4}$ produced by the thyroid gland is metabolized to biologically inactive sulfated forms, such as $\mathrm{T}_{4} \mathrm{~S}, \mathrm{~T}_{3} \mathrm{~S}$, and $\mathrm{rT}_{3} \mathrm{~S}$ (Wu et al. 1992, 1993). Thyroid hormones are sulfated by sulfotransferase, primarily in the fetal liver, but also in the kidneys, brain, and intestines (Fig. 1). One significant aspect of this metabolic pathway is that sulfation of thyroid hormones can be reversed by sulfatase enzymes in tissues such as the liver, lung, brain, and placenta (Richard et al. 2001, Kester et al. 2002). This means that $T_{3} S$, for example, can be converted back to $\mathrm{T}_{3}$, which is likely to be an important source of $\mathrm{T}_{3}$ especially during hypothyroidism (Fig. 1). In thyroidectomized sheep fetuses, $\mathrm{T}_{3} \mathrm{~S}$ remains in the circulation for up to 2 weeks while all other thyroid hormones and their metabolites fall below detectable levels ( $\mathrm{Wu}$ et al. 1993). Therefore, during hypothyroidism, $\mathrm{T}_{3} \mathrm{~S}$ conversion to $\mathrm{T}_{3}$ in tissues such as the brain maintains a local supply of $\mathrm{T}_{3}$ essential for normal growth and development. Indeed, the fetal brain employs several mechanisms to maintain normal local concentrations of thyroid hormones in the event of thyroid hormone deficiency. In the thyroidectomized sheep fetus, hepatic D1 activity is downregulated to reduce the endocrine deiodination of $\mathrm{T}_{4}$ in the fetal liver, while at the same time, cerebral D2 activity is upregulated to enhance local deiodination of $\mathrm{T}_{4}$ to $\mathrm{T}_{3}$ in the fetal brain (Polk et al. 1988). Therefore, the hypothyroid fetus conserves $T_{4}$ for local production of $T_{3}$ within the brain, in order to maintain the actions of the thyroid hormones on brain development.

For most of gestation, $\mathrm{T}_{4}$ is metabolized primarily to $\mathrm{rT}_{3}$ and a variety of sulfated thyroid hormones that are biologically inactive (Fig. 1). The high ratio of D3 to D1 activity in the fetal liver, and the placental D3 enzyme, maintain a high rate of $\mathrm{T}_{3}$ clearance and, therefore, concentrations of $T_{3}$ are relatively low in the fetal circulation. Toward term, however, there are developmental changes in tissue deiodinase activity and, therefore, plasma $\mathrm{T}_{3}$ concentration in the fetus (Darras et al. 1992, Forhead et al. 2006). In fetal sheep, hepatic and renal D1 activities increase, and placental D3 activity decreases, in the 2 weeks before birth (Forhead et al. 2006). Overall, preferential deiodination of $\mathrm{T}_{4}$ to $\mathrm{T}_{3}$ instead of $\mathrm{rT}_{3}$ and reduced clearance of $T_{3}$ lead to a rise in plasma $T_{3}$ concentration in the fetus near term. In fetal sheep, these maturational changes in tissue deiodinase activity have been shown to be induced by the prepartum cortisol

Published by Bioscientifica Ltd. 
surge and can be stimulated prematurely by maternal administration of the synthetic glucocorticoid, dexamethasone (Forhead et al. 2006, Forhead et al. 2007). Endogenous and synthetic glucocorticoids also increase plasma $\mathrm{T}_{3}$ conversion via changes in the hepatic D1:D3 ratio in the chick embryo (Darras et al. 1996). Therefore, circulating and local concentrations of thyroid hormones in the fetus are regulated developmentally, and in a tissuespecific manner, by the balance between deiodinase and other metabolic enzymes.

\section{Thyroid hormone transporters and receptors in fetal tissues}

Thyroid hormone bioavailability is also determined by the expression of transporters and intracellular receptors in the target tissues. There are several types of thyroid hormone transporters that allow the hormones access to target tissues, including organic anion transporters (OATP), L-type amino acid transporters (LAT1 and LAT2), and monocarboxylate transporters (MCT8 and MCT10; Friesema et al. 2005, Jansen et al. 2005). A genetic mutation in human MCT8 (SLC16A2) has been identified in families who showed symptoms of hypothyroidism including severe neurological and muscular defects, although the phenotype differs from that observed with congenital hypothyroidism and in mutant MCT8 mouse models (Visser et al. 2008, Heuer \& Visser 2013). In adult animals, thyroid hormone transporters have been identified in the liver, kidney, brain, lung, and placenta. In the cerebral cortex of the human fetus at 7-20 weeks of gestation, MCT8 and MCT10 (SLC16A10) mRNA levels are similar to those in the adult brain, and developmental changes in OATP (SLCO1A2) mRNA have been reported (Chan et al. 2011). Thyroid hormone transporter proteins in the brain and other tissues are likely to have an important role in determining tissue-specific bioavailability of the thyroid hormones in fetal as well as in adult life. Thus, variations in thyroid hormone transporter abundance may lead to abnormalities in thyroid hormone exposure even when circulating levels of these hormones are normal. However, to date, the regulation of these transporters in fetal tissues of any species is unknown.

Once transported across the plasma membrane, the bioactivity of thyroid hormones depends ultimately on the expression of intracellular TRs and post-receptorbinding pathways. The various TR $\alpha$ (THRA) and TR $\beta$ (THRB) isoforms are expressed in the fetus in a tissuespecific manner by mid-gestation and often at gestational ages earlier than the appearance of thyroid hormones in the fetal circulation (Table 1; Bernal \& Pekonen 1984, Nagasawa et al. 1997, White et al. 2001, Chan et al. 2002, 2005). These findings indicate that, for some species, maternal thyroid hormones may contribute to the control of early embryonic growth and development, before the onset of fetal thyroid hormone activity (Obregon et al. 2007). In addition, there are developmental changes in TR binding in the fetal brain, lung, skeletal muscle, liver, and heart as term approaches, which are also species specific (Bernal \& Pekonen 1984, Perez-Castillo et al. 1985, Ferreiro et al. 1987, Polk et al. 1989, Falcone et al. 1994, White et al. 2001). In fetal sheep, thyroid hormone binding is present in the liver and brain from 50 days and increases toward term in the liver (Ferreiro et al. 1987, Polk et al. 1989). Similarly, in fetal pigs, there are decreases in TR $\alpha$ expression in skeletal muscle and increases in TR $\beta$ abundance in the heart and skeletal muscle at birth (White et al. 2001). In both species, the gestational changes in fetal tissue TR abundance closely parallel plasma cortisol concentrations (Polk et al. 1989, White et al. 2001); however, the effect of the prepartum cortisol surge on the expression of thyroid hormone transporters and receptors in utero remains unknown. Furthermore, the developmental expression and potential roles of mitochondrial and plasma membrane receptors that bind thyroid hormones have not been investigated in fetal tissues to date (Chi et al. 2013). Tissue bioavailability of the thyroid hormones can, therefore, be varied either systemically by altering hormone secretion by the thyroid glands or at the local level by changes in the tissue transport, metabolism, and receptor milieux of the thyroid hormones.

\section{Placental transfer of maternal thyroid hormones}

In all mammalian species, the placenta actively transports iodide from the maternal to fetal circulation to provide iodide for thyroid hormone synthesis (Fig. 1). Gene expression of the sodium-iodide cotransporter is evident from 6 weeks of gestation in the human placenta and also present in the amniotic membrane at term (Li et al. 2012, Akturk et al. 2013). The transfer of thyroid hormones from the mother to fetus varies between mammalian species and types of placenta and is determined by the placental expression of thyroid hormone transporters, binding proteins, and D3 enzyme activity. The hemochorial placenta in human and rodent species has been shown to be relatively permeable to $\mathrm{T}_{4}$ and $\mathrm{T}_{3}$ (Calvo et al. 1992, Fisher 1997). A variety of thyroid hormone transporters are expressed in the human placenta and show changes

Published by Bioscientifica Ltd. 
during normal development and in cases of intrauterine growth restriction (IUGR; Chan et al. 2009, Loubiere et al. 2010). In isolated microvillous membrane vesicles of human syncytiotrophoblast at term, saturable uptake of $\mathrm{T}_{4}$ and $\mathrm{T}_{3}$ across the maternal apical surface occurs by mainly different types of thyroid hormone transporters (Loubiere et al. 2012). The thyroid hormone-binding protein, transthyretin (TTR), is expressed by the human placenta from at least 6 weeks of gestation and is upregulated in vitro by low oxygen levels (Landers et al. 2013). Therefore, placental TTR may facilitate the movement of thyroid hormones from the mother to fetus, especially in the low-oxygen environment of the first trimester.

Before the fetal thyroid gland is functional, the $\mathrm{T}_{4}$ concentrations measured in the amniotic fluid, and tissues and circulation of the fetus, are derived from the mother by transplacental transfer. Indeed, $\mathrm{T}_{4}$ has been detected in coelomic fluid from as early as 4 weeks post-conception, which demonstrates that the embryo is exposed to maternal thyroid hormones from early in development (Contempre et al. 1993). Once the fetus is able to produce its own thyroid hormones, maternal $\mathrm{T}_{4}$ makes only a modest contribution to the total concentration in the fetus. In the rat near term, maternally derived $\mathrm{T}_{4}$ accounts for about $15 \%$ of the concentration in the fetal circulation (Morreale de Escobar et al. 1990). Therefore, in human and rodent fetuses, maternal thyroid hormones may have an important role in fetal development, especially during the first and second trimesters. Placental transfer of maternal thyroid hormones may become particularly important in conditions of fetal hypothyroidism, when the steep gradient in thyroid hormones from the mother to fetus may aid fetal acquisition of maternal hormones transplacentally. In human fetuses with total thyroid deficiency, cord $\mathrm{T}_{4}$ concentrations are $20-50 \%$ of normal values and decrease rapidly soon after birth (Vulsma et al. 1989). By contrast, the epitheliochorial placenta of the sheep appears to be impermeable to maternal thyroid hormones, at least at 0.75 of gestation, and there is negligible materno-fetal transfer, even during fetal hypothyroidism (Hopkins \& Thorburn 1972). The effectiveness of the ovine placenta as a thyroid hormone barrier means that the sheep fetus is dependent upon development of its own thyroid hormone axis in utero. The thyroidectomized sheep fetus is, therefore, a useful experimental model to examine the effects of thyroid hormones on aspects of fetal growth and maturation, independent of maternal thyroid status.

\section{Thyroid hormones and fetal growth}

Thyroid hormone concentrations are low in IUGR and small-for-gestational-age fetuses both in human populations and when fetal growth is restricted in experimental animals by undernutrition and placental insufficiency (Wrutniak \& Cabello 1983, Thorpe-Beeston et al. 1991b, Kilby et al. 1998, Rae et al. 2002, Pereira \& Procianoy 2003). In several of the experimental studies, plasma $\mathrm{T}_{4}$ concentrations are correlated positively to the body weight of the fetal and/or newborn animals (Wrutniak \& Cabello 1983, Fowden \& Silver 1995). Similarly, in normal human infants, umbilical $\mathrm{T}_{4}$ concentrations are positively related to body weight and length at birth (Sack et al. 1993, Shields et al. 2011). In addition, TR binding in skeletal muscle is lower in newborn runts compared with normal-sized piglets (Dauncey \& Geers 1990), and immunostaining for the TR isoforms and thyroid hormone transporter, MCT8, are reduced in the occipital cerebral cortex of IUGR human fetuses (Kilby et al. 2000, Chan et al. 2014). Collectively, the clinical and experimental findings indicate that bioavailability of thyroid hormones in utero regulates fetal growth by acting as a signal of the nutrient and oxygen supply to the fetus (Fowden \& Forhead 2009). In addition, when IUGR is progressive or severe, impaired fetal growth per se may alter thyroid hormone status by evoking a fetal stress response and secretion of stress hormones such as the glucocorticoids that affect thyroid hormone bioavailability indirectly (Fowden \& Forhead 2009).

The growth regulatory effects of the thyroid hormones have been studied more specifically by direct manipulation of thyroid hormone concentrations in utero in experimental animals. In species with little, if any, placental transfer of maternal thyroid hormones, such as sheep, goats, horses, and pigs, hypothyroidism induced congenitally or by surgical ablation of the fetal thyroid gland(s) causes growth restriction of the fetus (Table 2; Spencer et al. 1989, Piosik et al. 1997, Allen et al. 1998). These studies show that fetal thyroid hormones are required for both accretion of fetal mass and differentiation of specific cell types, such as the wool or hair follicles, at critical stages of development well before term (Table 2; Hopkins \& Thorburn 1972, Hausman 1992). Thus, in sheep, the severity of the developmental abnormalities is related to both the stage of development at the time of thyroidectomy and the duration of thyroid hormone deficiency (Table 2). In animals with greater placental permeability to maternal thyroid hormones, such as rabbits, rodents, and human and non-human primates, the effects of fetal thyroid hormone deficiency

Published by Bioscientifica Ltd 
Table 2 Effects of thyroidectomy in utero on the growth and development of the sheep fetus

\begin{tabular}{|c|c|c|c|c|c|c|c|}
\hline \multirow[b]{3}{*}{$\begin{array}{l}\text { Age at } \\
\text { surgery }\end{array}$} & \multirow[b]{3}{*}{$\begin{array}{l}\text { Age at } \\
\text { study }\end{array}$} & \multicolumn{4}{|c|}{ Percentage of euthyroid control } & \multirow[b]{3}{*}{ Specific tissue abnormalities } & \multirow[b]{3}{*}{ References } \\
\hline & & \multirow[b]{2}{*}{$\begin{array}{l}\text { Body } \\
\text { weight }\end{array}$} & \multicolumn{3}{|c|}{ Length } & & \\
\hline & & & $\begin{array}{l}\text { Crown- } \\
\text { rump }\end{array}$ & Forelimb & Hindlimb & & \\
\hline 73 & 140 & 72 & - & - & 90 & $\begin{array}{l}\text { Smaller area of type II muscle fibers } \\
\text { Decreased force generation in skeletal } \\
\text { muscle }\end{array}$ & Finkelstein et al. (1991) \\
\hline 80 & 135 & 74 & - & - & - & $\begin{array}{l}\text { Altered autonomic nervous system } \\
\text { function }\end{array}$ & Walker \& Schuijers (1989) \\
\hline 80 & 145 & 67 & - & - & - & $\begin{array}{l}\text { Delayed epiphyseal closure } \\
\text { Increased relative brain weight } \\
\text { Fewer type II pneumocytes, anemia }\end{array}$ & Ayromlooi et al. (1983) \\
\hline \multirow[t]{2}{*}{88} & 144 & 67 & 91 & 74 & 76 & Delayed bone maturation & $\begin{array}{l}\text { Hopkins \& Thorburn } \\
\text { (1972) }\end{array}$ \\
\hline & & & & & & $\begin{array}{l}\text { Reduced relative thymus weight } \\
\text { No wool follicle development }\end{array}$ & \\
\hline 101 & 135 & 60 & 100 & 100 & 100 & $\begin{array}{l}\text { Reduced relative lung weight } \\
\text { Reduced protein content in specific tissues } \\
\text { Thin skin, abnormal wool development }\end{array}$ & Erenberg et al. (1974) \\
\hline 103 & 137 & 72 & - & - & - & Increased relative brain weight & $\begin{array}{l}\text { Bhakthavathsalan et al. } \\
\text { (1977) }\end{array}$ \\
\hline \multirow[t]{2}{*}{103} & 130 & 91 & 99 & 92 & 86 & Altered bone strength and mineral density & Lanham et al. (2011) \\
\hline & 144 & 74 & 86 & 82 & 83 & Delayed bone maturation & \\
\hline \multirow[t]{2}{*}{105} & 135 & 78 & 89 & 85 & 84 & Reduced hemoglobin levels & Fowden \& Silver (1995) \\
\hline & 139 & 81 & 90 & 88 & 87 & $\begin{array}{l}\text { Reduced catecholaminergic response to } \\
\text { fasting }\end{array}$ & Fowden et al. (2001a) \\
\hline \multirow[t]{2}{*}{120} & 130 & 100 & - & - & - & Reduced relative heart weight & $\begin{array}{l}\text { Chattergoon et al. } \\
\quad(2012 a)\end{array}$ \\
\hline & & & & & & $\begin{array}{l}\text { Increased relative kidney weight } \\
\text { Fewer binucleated cardiomyocytes }\end{array}$ & \\
\hline 125 & 132 & 100 & - & - & - & Fewer binucleated cardiomyocytes & Segar et al. (2013) \\
\hline 129 & 145 & 100 & - & - & - & $\begin{array}{l}\text { Abnormal neonatal cardiovascular } \\
\text { adaptations }\end{array}$ & Breall et al. (1984) \\
\hline
\end{tabular}

on intrauterine growth are less pronounced (Jost 1979, Fowden \& Forhead 2009, Hall et al. 2010), which suggests that maternal thyroid hormones compensate, in part, for the fetal deficiency. Human infants with congenital hypothyroidism are often born with a normal bodyweight, although they may have neurological and skeletal abnormalities consistent with the tissue-specific developmental effects of thyroid hormones observed in other animals (Vulsma et al. 1989, Patel et al. 2011, Shields et al. 2011). Certainly, when maternal and fetal hypothyroidism are combined during pregnancy, there are severe consequences for the development of the neuromotor, auditory, cardiovascular, skeletal, and respiratory systems of the human infant (De Zegher et al. 1995, Yasuda et al. 1999).

In fetal sheep, thyroidectomy reduces bodyweight, individual organ weights, and skeletal growth of the vertebrae and limbs (Table 2). The changes in the body weight and vertebral and limb length of thyroidectomized fetuses can be ameliorated by $\mathrm{T}_{4}$ replacement (Fowden $\&$ Silver 1995, Fowden et al. 2001a). The protein content of fetal tissues such as the heart, lung, and skeletal muscle is also reduced by fetal thyroidectomy (Erenberg et al. 1974). The growth restriction of thyroidectomized fetuses is asymmetrical with greater effects on the weight of soft tissues than on the length of bones, although brain sparing occurs as observed in other types of IUGR (Table 2). The appendicular skeleton is also more adversely affected than the axial skeleton of thyroidectomized fetuses (Table 2). The abnormalities in bone structure and mechanical properties after fetal thyroidectomy are associated with a reduction in the circulating levels of osteocalcin, a marker of osteoblast activity, without any change in the plasma concentrations of total calcium or markers of osteoclast activity (Hopkins \& Thorburn 1972, Lanham et al. 2011). These findings suggest that hypothyroidism delays bone development by reducing normal bone deposition rather than by changing the rate of bone degradation or

Published by Bioscientifica Ltd. 
calcium homeostasis in utero (Lanham et al. 2011). Thyroid hormones, therefore, promote both general body growth and the development of individual tissues of the fetus.

\section{Metabolic effects of the thyroid hormones}

Thyroid hormones act on fetal growth via direct and indirect mechanisms. First, thyroid hormones have direct actions on fetal metabolism, particularly on the consumption of oxygen $\left(\mathrm{O}_{2}\right)$ and glucose. Infusion of $\mathrm{T}_{3}$ into fetal sheep for 5 days increases fetal $\mathrm{O}_{2}$ consumption by $28 \%$ in association with increases in fetal cardiac output and umbilical blood flow (Lorijn \& Longo 1980, Lorijn et al. 1980). Conversely, the weight-specific rates of fetal $\mathrm{O}_{2}$ consumption and oxidation of glucose carbon are reduced by $20-30 \%$ by thyroidectomy of fetal sheep and restored to normal values by $\mathrm{T}_{4}$ replacement (Fowden \& Silver 1995). Availability of $\mathrm{T}_{4}$ has also been shown to regulate glucose oxidation in adipose tissue of fetal pigs (Hausman et al. 1996). In addition, fetal hypothyroidism prevents the normal fall in fetal glucose oxidation observed in response to short-term fasting of pregnant ewes (Fowden et al. 2001a). The reduced $\mathrm{O}_{2}$ consumption of thyroidectomized sheep fetuses occurs without any alteration in the weightspecific rate of umbilical blood flow but is accompanied by fetal anemia and a reduction in blood $\mathrm{O}_{2}$ content (Fowden $\&$ Silver 1995). The causes of the changes in fetal $\mathrm{O}_{2}$ consumption, therefore, appear to differ between hypothyroidism and hyperthyroidism although this may reflect, in part, the duration of exposure to abnormal thyroid hormone concentrations. Overall, circulating $\mathrm{T}_{4}$ and $\mathrm{T}_{3}$ concentrations correlate positively with the wholebody rate of $\mathrm{O}_{2}$ consumption in the fetus (Lorijn \& Longo 1980, Lorijn et al. 1980, Fowden \& Silver 1995). However, there are no changes in $\mathrm{O}_{2}$ consumption by the liver, kidney, brain, or placenta of thyroidectomized fetuses, which suggests that the primary oxidative action of the thyroid hormones is on fetal fat and skeletal muscle (Bhakthavathsalan et al. 1977, Klein et al. 1983, Polk et al. 1987, Fowden \& Silver 1995, Herpin et al. 1996). Certainly, in fetal sheep, there is an increase in the proportion of the anaerobic type II muscle fibers in several muscles after fetal thyroidectomy consistent with the more limited oxidative capacity observed in these circumstances (Finkelstein et al. 1991, Fowden \& Silver 1995).

At the cellular level, thyroid hormones can influence oxidative metabolism either by changing expression and activity of the electrogenic $\mathrm{Na}^{+}-\mathrm{K}^{+}$ATPase pump or by acting on the mitochondrial electron transport chain (ETC) and oxidative phosphorylation per se (Wrutniak et al. 1998, Ramminger et al. 2002, Patel et al. 2011). In vitro studies have shown that $\mathrm{T}_{4}$ and $\mathrm{T}_{3}$ increase the amount and activity of $\mathrm{Na}^{+}-\mathrm{K}^{+}$ATPase pumps in cultured skeletal myotubes and pulmonary epithelial cells from fetal rats close to term (Brodie \& Sampson 1988, Ramminger et al. 2002). However, no changes in $\mathrm{Na}^{+}-\mathrm{K}^{+}$ATPase pump activity are observed in the liver, kidney, or brain of thyroidectomized fetal sheep during late gestation (Klein et al. 1983). Mitochondrial contents of total protein and cytochrome $c$ oxidase, a component of the ETC, are reduced by prenatal hypothyroidism in skeletal muscle and liver of fetal and newborn pigs (Herpin et al. 1996). Similarly, cerebral cytochrome $c$ oxidase is reduced in hypothyroid rat fetuses without a change in mitochondrial DNA content (Vega-Nunez et al. 1995). In addition, in fetal sheep, plasma $T_{3}$ concentrations are positively related to adipose tissue expression of the mitochondrial uncoupling proteins 1 and 2 (UCP1 and UCP2), which dissipate the mitochondrial proton gradient and reduce the efficiency of ATP production (Mostyn et al. 2003, Gnanalingham et al. 2005). Taken together, these observations suggest that thyroid hormones affect mitochondrial respiration, biogenesis, and ATP generation in a tissue-specific manner. However, whatever the specific mechanisms involved, hypothyroid fetuses will derive less ATP from oxidative metabolism than euthyroid fetuses and, thus, have less energy available for growth of nonessential tissues. Thyroid hormones, therefore, stimulate fetal growth through oxidative actions on fetal metabolism (Fig. 2).

\section{Thyroid hormones and the insulin-like growth factors}

A second, indirect mechanism by which thyroid hormones may influence fetal development is through interactions with other endocrine systems involved in regulating intrauterine growth (Fowden \& Forhead 2013). Through changes in tissue or plasma levels and/or receptor abundance, manipulation of thyroid hormone concentrations in utero has been shown to affect the fetal bioavailability of several hormones and growth factors including the renin-angiotensin system, catecholamines, leptin, prostaglandins, growth hormone $(\mathrm{GH})$, and the insulin-like growth factors (IGFs; Walker \& Schuijers 1989, Richards et al. 1993, Forhead et al. 1998, 2000a,b, Fowden et al. 2001a, Forhead \& Fowden 2002, Chen et al. 2005, 2007, Liu et al. 2005, O'Connor et al. 2007, Carey et al. 2008). For instance, thyroid hormones are known to be involved in the neonatal epigenetic modifications of the hippocampal glucocorticoid receptors that have long-term

Published by Bioscientifica Ltd 


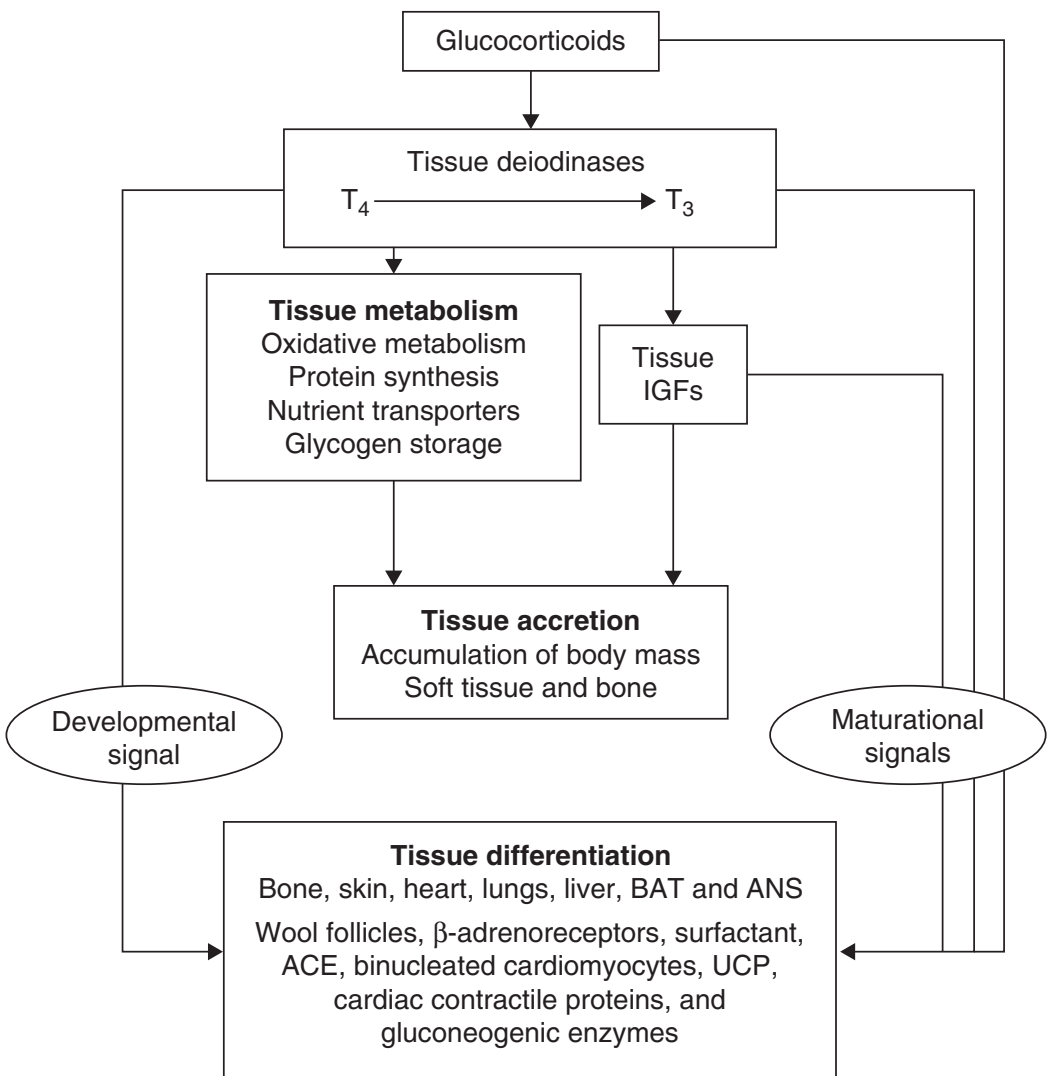

\section{Figure 2}

Schematic diagram showing the role of the thyroid hormones in the growth and development of the fetus during the second half of gestation. $\mathrm{T}_{4}$, thyroxine; $\mathrm{T}_{3}$, triiodothyronine; $\mathrm{BAT}$, brown adipose tissue;

consequences for the function of the adult hypothalamicpituitary-adrenal axis (Champagne 2013). In particular, their role in regulating the somatotropic axis and local tissue expression of the IGFs is likely to have important implications for growth and development in utero.

The IGFs are expressed widely in fetal tissues and are known to have an important role in fetal and placental growth (Fowden 2003, Forbes \& Westwood 2008). Their expression in utero also varies with gestational age and nutritional state in a tissue-specific manner (Fowden \& Forhead 2009). In fetal sheep and pigs, plasma IGF1 but not IGF2 concentrations are reduced by hypothyroidism and restored to normal values by $\mathrm{T}_{4}$ treatment (Mesiano et al. 1987, Latimer et al. 1993). These changes are accompanied by alterations in tissue expression of the IGF1 but not the IGF2 gene (Fowden et al. 2006). In hypothyroid fetal pigs, the reduction in tissue IGF1 content is widespread whereas, in thyroidectomized fetal sheep, changes in IGF1 mRNA expression are tissue specific with decreases in skeletal muscle and increases
ANS, autonomic nervous system; $A C E$, angiotensin-converting enzyme; UCP, uncoupling protein.

in the liver (Latimer et al. 1993, Forhead et al. 1998, $2000 a, b, 2002)$. Manipulation of thyroid hormone levels in fetal sheep also alters plasma GH concentrations and hepatic expression of the GH receptor (GHR; Richards et al. 1993, Forhead et al. 2000a,b). Furthermore, prevention of the normal prepartum rise in $\mathrm{T}_{3}$ concentrations by thyroidectomy of fetal sheep modifies the normal ontogenic pattern of expression of the GHR and $I G F$ genes in both liver and skeletal muscle toward term (Forhead et al. 1998, 2000b, 2002). Thus, thyroid hormones appear to regulate not only general tissue accretion but also terminal differentiation of fetal tissues in preparation for extrauterine life (Fig. 2).

\section{Thyroid hormones and fetal maturation}

Toward term, there are maturational changes in a wide range of fetal tissues in preparation for extrauterine life, which are dependent on the prepartum rise in fetal cortisol concentrations (Fowden et al. 1998). These changes ensure

Published by Bioscientifica Ltd. 
activation of physiological processes essential for survival immediately at birth such as pulmonary gas exchange, adaptations in cardiac function, hepatic glucogenesis, and thermogenesis. The cortisol-induced maturational changes include the ontogenic changes in tissue D3 and D1 deiodinase activities and the concomitant increase in circulating $\mathrm{T}_{3}$ concentration in the fetus toward term (Forhead et al. 2006, Fowden \& Forhead 2009). In turn, the prepartum increase in $\mathrm{T}_{3}$ bioavailability in the fetus may mediate, at least in part, the maturational effects of both endogenous cortisol and exogenous synthetic glucocorticoids given as a clinical treatment to improve neonatal viability in threatened pre-term delivery.

\section{The lungs and respiratory function}

Ventilation of the lungs and gas exchange in the newborn animal depend on a number of structural and functional changes, including removal of lung liquid and production of surfactant (Olver et al. 1981, Wilson et al. 2007, Hillman et al. 2012). Thyroid hormones have an important role in determining the sensitivity of the fluid absorption system to catecholamines released during birth (Barker et al. 1988, 1990, 1991). Toward term, the ability of epinephrine and cAMP to switch lung liquid secretion to absorption increases progressively (Barker et al. 1988). This maturational process is impaired in thyroid-deficient sheep fetuses, but can be restored by replacement infusion of $\mathrm{T}_{3}$ or $\mathrm{T}_{4}$ (Barker et al. 1990). Antenatal $\mathrm{T}_{3}$ administration can also improve pulmonary function in newborn lambs delivered prematurely (Chan et al. 1998). However, both cortisol and $\mathrm{T}_{3}$ are required for epinephrine-induced lung liquid absorption and act synergistically via mechanisms that depend on protein synthesis (Barker et al. 1991, Ramminger et al. 2002). These effects are probably mediated by upregulation of the pulmonary $\beta$-adrenergic receptors (Das et al. 1984, Warburton et al. 1988), but as thyroid hormones influence cAMP responsiveness, they may also involve intracellular signaling pathways downstream of the receptors (Barker et al. 1988, Wilson et al. 2007). Thyroid hormones are known to increase the expression of pulmonary $\beta$-adrenergic receptors and apical $\mathrm{Na}^{+}$channels in the fetus and can stimulate the expression and activity of the $\mathrm{Na}^{+} / \mathrm{K}^{+}$ATPase in the basolateral membrane of the alveolar epithelium (Das et al. 1984, Warburton et al. 1988, Wilson et al. 2007).

Maturation of surfactant synthesis and release by the type II pneumocytes also depends, in part, on the increasing $\mathrm{T}_{3}$ bioavailability toward term (Mendelson \& Boggaram 1991, Hillman et al. 2012). Thyroidectomy of fetal sheep reduces the number of type II pneumocytes in the lungs at term as well as the number of surfactantcontaining lamellar bodies in these cells (Ayromlooi et al. 1983). In vitro and in vivo studies have shown that thyroid hormones affect synthesis of both the phospholipid and protein components of surfactant in fetal mice, rats, sheep, monkeys, and human infants (Ballard et al. 1984, Das et al. 1984, Torday \& Dow 1984, Warburton et al. 1988, Romaguera et al. 1993, Gilbert et al. 2001, van Tuyl et al. 2004). In particular, thyroid hormones promote synthesis of surfactant proteins B and C. They also increase the phospholipid content of lung liquid, although this effect may be mediated via upregulation of pulmonary $\beta$-adrenergic receptor expression and, hence, enhanced epinephrine-stimulated surfactant release (Das et al. 1984, Warburton et al. 1988). Similar to lung liquid resorption, the effects of $\mathrm{T}_{3}$ and cortisol on surfactant production appear to be synergistic with greater effects on lung stability when the two hormones are given together than when either hormone is given alone (Warburton et al. 1988, Mendelson \& Boggaram 1991, Hillman et al. 2012).

Finally, thyroid hormones can affect lung maturation via actions on the expression of angiotensin-converting enzyme (ACE) in the pulmonary vascular endothelium. In postnatal lungs, angiotensin I is activated to angiotensin II by ACE as the cardiac output circulates through the pulmonary vasculature. However, before birth, the fetal lungs are poorly perfused and pulmonary ACE levels are relatively low. In fetal sheep toward term, there is a rise in pulmonary ACE concentration, in association with the prepartum changes in plasma cortisol and $\mathrm{T}_{3}$, which is abolished by thyroidectomy and can be stimulated prematurely by $\mathrm{T}_{3}$ infusion (Forhead et al. 2000a, Forhead $\&$ Fowden 2002). Upregulation of pulmonary ACE by $\mathrm{T}_{3}$ may activate the fetal renin-angiotensin system near term and may have implications for the maturation of cardiovascular and renal function as well as for local pulmonary development.

\section{The heart and cardiovascular function}

Thyroid hormones are also essential for the normal maturation of cardiomyocytes and the cardiovascular system (Thornburg et al. 2011). They promote a switch from proliferation to hypertrophy and differentiation of the cardiomyocytes both at term and earlier in gestation (Chattergoon et al. 2012a,b). In a series of in vivo and in vitro studies in fetal sheep, $\mathrm{T}_{3}$ has been shown to increase the cardiomyocyte size and the population of terminally differentiated binucleated cells in association

Published by Bioscientifica Ltd 
with downregulation of cell cycle promoters by $50 \%$ or more and upregulation of cell cycle suppressors and various molecular mechanisms of cell growth by up to 500\% (Chattergoon et al. 2007, 2012a,b). Conversely, thyroidectomy of the sheep fetus reduces the number of binucleate cardiomyocytes by $27 \%$ and the relative weight of the heart by $10-15 \%$ near term (Chattergoon et al. 2012a, Segar et al. 2013). In rodents, $T_{3}$ has been shown to have anabolic effects on the fetal heart with increases in cardiac protein synthesis and expression of the insulinsensitive glucose transporter, GLUT4 (Crie et al. 1983, Castello et al. 1994). These thyroid hormone-dependent changes in cardiomyocyte growth and differentiation are accompanied by alterations in expression of contractile proteins, mechano-signaling proteins, and various genes coding for cardiac pacemaker, potassium channels, and sarcoplasmic reticulum calcium pump proteins (Edwards et al. 1994, Mai et al. 2004, van Tuyl et al. 2004, Kruger et al. 2008, Chattergoon et al. 2012a, Segar et al. 2013). In particular, the thyroid hormones have an important role in the perinatal switch from $\beta$ - to $\alpha$-myosin heavy chains in the sacromeres (Edwards et al. 1994, van Tuyl et al. 2004). Many of these maturational effects of $T_{3}$ on cardiac contractility appear to be mediated via the phosphatidylinositol-3-kinase/AKT and mTOR pathways (Kruger et al. 2008, Chattergoon et al. 2012a). Thyroid hormones also affect the atrial natriuretic peptide content of the fetal heart and have an important role in coordinating maturation of the absolute and relative abundance of the multiple adrenergic receptor subtypes in the fetal heart (Birk et al. 1992, Metz et al. 1996, Mai et al. 2004, Chattergoon et al. 2012a). In particular, they are essential for prepartum upregulation of the $\beta$-adrenergic receptors and, thus, cardiac responsiveness to $\beta$-agonists (Birk et al. 1992, Chen et al. 2005).

The cellular changes induced in the fetal heart by thyroid hormones have major implications for cardiac function both in utero and during the transition to extrauterine life. At birth, the two sides of the heart have to switch from pumping in parallel to pumping in series and, on the left side, this has to occur against a greater pressure caused by the loss of the low resistance placental pathway. Indeed, recent studies have shown that thyroid hormones are essential for the adaptation and growth of the fetal ovine heart in response to a pressure overload during late gestation (Segar et al. 2013). Fetal blood pressure and heart rate are reduced by about $10-25 \%$ by thyroidectomy of fetal sheep depending on the gestational age at surgery and the duration of hypothyroidism (Breall et al. 1984, Walker \& Schuijers 1989, Chen et al. 2005,
2007, Segar et al. 2013). Conversely, $\mathrm{T}_{3}$ infusion into euthyroid fetal sheep near term causes tachycardia accompanied by increases in fetal cardiac output and pulmonary blood flow (Lorijn \& Longo 1980). Fetal thyroidectomy abolishes the inotropic effect of the $\beta$-adrenergic agonist, isoprenaline, and prevents the fetal bradycardia and hypertension normally observed in response to hypoxemia, despite elevated basal circulating concentrations of norepinephrine in the fetus (Walker \& Schuijers 1989, Birk et al. 1992, Chen et al. 2005). Fetal hypothyroidism also prevents the increases in heart rate, cardiac output, blood pressure, and systemic blood flow normally observed in newborn lambs in the hours after delivery (Breall et al. 1984). In part, the lack of an appropriate cardiovascular response to fetal hypoxemia and delivery per se is due to the paucity of cardiac $\beta$-adrenergic receptors and may also reflect abnormalities in functioning of the baroreflex and autonomic nervous system more generally (Walker \& Schuijers 1989, Chen et al. 2005). Changes in perinatal cardiovascular function in response to manipulation of thyroid hormone levels may, therefore, involve more than cardiac adaptations alone. Certainly, there are changes in catecholamine content and abundance of receptors for vasoactive agents such as the angiotensin II and the catecholamines in several fetal tissues after fetal thyroidectomy (Walker \& Schuijers 1989, Forhead \& Fowden 2002, Chen et al. 2005, 2007, Liu et al. 2005). Indeed, a poor catecholaminergic response to hypoglycemia appears to be a contributory factor to the metabolic abnormalities observed in thyroidectomized fetuses of fasted ewes (Fowden et al. 2001a).

\section{The liver and glucogenesis}

At birth, there is activation of hepatic glucogenesis to maintain a glucose supply to neonatal tissues during the period between placental separation and the onset of nutritive suckling (Fowden et al. 2001b, Hillman et al. 2012). This depends on adequate glycogen stores and gluconeogenic enzyme activities in the liver (Fowden et al. 1998, 2001b). The normal developmental increments in hepatic glycogen, and hepatic and renal gluconeogenic enzymes, are abolished in hypothyroid sheep fetuses (Forhead et al. 2003, 2009). Fetal thyroidectomy also prevents activation of fetal glucogenesis in response to maternal fasting during late gestation, which is accompanied by low hepatic glycogen levels and a failure to increase key gluconeogenic enzyme activities (Fowden et al. 2001a). Both fasting-induced fetal glucogenesis and the normal prepartum increases in hepatic glycogen

Published by Bioscientifica Ltd 
and gluconeogenic enzyme activities are dependent on the increase in cortisol secretion by the fetal adrenal glands (Fowden et al. 1998). As cortisol but not $T_{3}$ levels rise normally in thyroidectomized fetuses (Forhead et al. 2002 , 2003), the reduced glucogenic capacity of these fetuses suggests that the effects of prepartum cortisol surge are mediated by the concomitant increase in $\mathrm{T}_{3}$ production. Certainly, the normal positive correlations observed between fetal cortisol concentrations and the hepatic activities of the rate-limiting gluconeogenic enzymes, glucose-6-phosphatase (G6Pase) and phosphoenolpyruvate carboxykinase (PEPCK), are absent in thyroidectomized fetuses in late gestation (Fowden et al. 2001a). Furthermore, $\mathrm{T}_{3}$ treatment of immature euthyroid sheep fetuses causes an increase in hepatic G6Pase and PEPCK activities in the presence of low cortisol concentrations (Forhead et al. 2003). Thyroid hormones, therefore, have an important role in ensuring that hepatic gluconeogenesis can be activated at birth.

\section{Adipose tissue and thermogenesis}

At birth, the mammalian neonate must maintain its body temperature for the first time. This requires more heat production than in utero, so, depending on the species, shivering and/or non-shivering thermogenesis are initiated at birth (Silva 2011). Activation of non-shivering thermogenesis, in particular, requires thyroid hormones. In sheep, thyroidectomy in utero reduces body temperature after birth and prevents the neonatal increase in $\mathrm{O}_{2}$ consumption by the lamb as a whole and by certain of its tissues such as the liver, brain, and brown adipose tissue (Klein et al. 1983, Breall et al. 1984, Polk et al. 1987, Schermer et al. 1996). It also reduces thermogenic activity of the perirenal brown adipose tissue used for nonshivering thermogenesis, coincident with an increase in the incidence of shivering to help maintain core temperature (Schermer et al. 1996). In addition, norepinephrine is less effective at stimulating $\mathrm{O}_{2}$ consumption by brown adipose tissue from newborn lambs thyroidectomized in utero 2 weeks before delivery (Polk et al. 1987). Similarly, inactivating the $\mathrm{D} 2$ deiodinase that produces $\mathrm{T}_{3}$ in brown adipose tissue impairs the oxidative capacity and heat production of newborn mice (Hall et al. 2010).

The thermogenic actions of the thyroid hormones are due, in part, to upregulation of UCP abundance and other mitochondrial proteins in brown adipose tissue and the uncoupling of the mitochondrial proton-motive force from ADP phosphorylation to release the energy as heat (Guerra et al. 1994, Schermer et al. 1996,
Gnanalingham et al. 2005). However, direct administration of $T_{3}$ to fetal sheep before birth does not activate thermogenesis by brown adipose tissue, even when the fetus is cooled (Schroder et al. 1987, Power et al. 1989), although it does augment thermogenesis and $\mathrm{O}_{2}$ consumption in response to catecholamines and cAMP by fetal brown adipose tissue in vitro after $\mathrm{T}_{3}$ infusion in vivo (Klein et al. 1984). This has lead to the suggestion that placental factors inhibit activation of thermogenesis by brown adipose tissue until after delivery (Power et al. 1989, Symonds et al. 2003). However, by upregulation of $\beta$-adrenergic receptor abundance and/or downstream components of the signaling pathway in brown adipose tissue as occurs in fetal lung and other tissues, thyroid hormones may increase the effectiveness with which the sympathetic nervous system can stimulate thermogenesis in the neonate (Symonds et al. 2003, Hillman et al. 2012). Thus, thyroid hormones appear to have a maturational role in enhancing the thermogenic capacity of brown adipose tissue toward term but may not be the direct stimulus for initiating non-shivering thermogenesis immediately after birth.

\section{Conclusions}

Thyroid hormones have an essential role in fetal development. They stimulate intrauterine growth during the second half of gestation through anabolic actions on fetal metabolism and effects on growth regulatory factors and endocrine systems (Fig. 2). They also have discrete actions in triggering specific developmental events such as differentiation of the wool follicles and binucleated cardiomyocytes (Fig. 2). In addition, the prepartum rise in $\mathrm{T}_{3}$ bioavailability has an important role in mediating several of the maturational effects of the glucocorticoids in late gestation. Often, $\mathrm{T}_{3}$ and cortisol act synergistically to switch the cell cycle from accretion to differentiation in a range of fetal tissues essential for neonatal survival (Fig. 2). Several of the prepartum maturational changes induced by the thyroid hormones increase the functionality of the sympathetic nervous system. In turn, this improves the response of the neonate to the stress of delivery and aids its adaptation to the new extrauterine environment. Indeed, the effects of an altered thyroid hormone status during intrauterine development may have lifelong consequences through permanent changes in the structure and function of tissues and organ systems. However, the extent to which thyroid hormones alter development of the tissues, such as the autonomic nervous system, either prenatally or in the long term

Published by Bioscientifica Ltd. 
and the mechanisms by which these hormones act at the cellular and molecular levels in utero still remain largely unknown.

\section{Declaration of interest}

The authors declare that there is no conflict of interest that could be perceived as prejudicing the impartiality of the review.

\section{Funding}

This review did not receive any specific grant from any funding agency in the public, commercial or not-for-profit sector.

\section{Acknowledgements}

The authors would like to thank all members of the staff of the Department of Physiology, Development and Neuroscience who have helped with our studies over the years. Some of the research by the authors described here was funded by the BBSRC.

\section{References}

Akturk M, Oruc AS, Danisman N, Erkek S, Buyukkagnici U, Unlu E \& Tazebay UH $2013 \mathrm{Na}^{+} / \mathrm{I}^{-}$symporter and type 3 iodothyronine deiodinase gene expression in amniotic membrane and placenta and its relationship to maternal thyroid hormones. Biological Trace Element Research 154 338-344. (doi:10.1007/s12011-013-9748-y)

Allen AL, Fretz PB, Card CE \& Doige CE 1998 The effects of partial thyroidectomy on development of the equine fetus. Equine Veterinary Journal 30 53-59. (doi:10.1111/j.2042-3306.1998.tb04088.x)

Ayromlooi J, Berg PD, Valderrama E \& Tobias MD 1983 Midtrimester thyroidectomy in the ovine fetus. Pediatric Pharmacology 3 15-28.

Ballard PL, Hovey ML \& Gonzales LK 1984 Thyroid hormone stimulation of phosphatidylcholine synthesis in cultured fetal rabbit lung. Journal of Clinical Investigation 74 898-905. (doi:10.1172/JCI111507)

Barker PM, Brown MJ, Ramsden CA, Strang LB \& Walters DV 1988 The effects of thyroidectomy in the fetal sheep on lung liquid reabsorption induced by adrenaline or cyclic AMP. Journal of Physiology 407 372-383.

Barker PM, Strang LB \& Walters DV 1990 The role of thyroid hormones in maturation of the adrenaline-sensitive lung liquid reabsorptive mechanism in fetal sheep. Journal of Physiology 424 473-485.

Barker PM, Walters DV, Markiewicz M \& Strang LB 1991 Development of the lung liquid reabsorptive mechanism in fetal sheep: synergism of triiodothyronine and hydrocortisone. Journal of Physiology $\mathbf{4 3 3}$ 435-449.

Bernal J \& Pekonen F 1984 Ontogenesis of the nuclear 3,5,3'-triiodothyronine receptor in the human fetal brain. Endocrinology 114 677-679. (doi:10.1210/endo-114-2-677)

Bhakthavathsalan A, Mann LI, Ayromlooi J, Kunzel W \& Liu M 1977 The effects of fetal thyroidectomy in the ovine fetus. American Journal of Obstetrics and Gynecology 127 278-284.

Bianco AC, Salvatore D, Gereben B, Berry MJ \& Larsen PR 2002 Biochemistry, cellular and molecular biology, and physiological roles of the iodothyronine selenodeiodinases. Endocrine Reviews 23 38-89. (doi:10.1210/edrv.23.1.0455)

Birk E, Tyndall MR, Erickson JC, Rudolph AM \& Roberts JM 1992 Effects of thyroid hormone on myocardial adrenergic $\beta$-receptor responsiveness and function during late gestation. Pediatric Research 31 468-473. (doi:10.1203/00006450-199205000-00011)
Breall JA, Rudolph AM \& Heymann MA 1984 Role of thyroid hormones in postnatal circulatory and metabolic adaptations. Journal of Clinical Investigation 73 1418-1424. (doi:10.1172/JCI111346)

Brent GA 2012 Mechanisms of thyroid hormone action. Journal of Clinical Investigation 122 3035-3043. (doi:10.1172/JCI60047)

Brodie C \& Sampson SR 1988 Characterization of thyroid hormone effects on $\mathrm{Na}-\mathrm{K}$ pump and membrane potential of cultured rat skeletal muscle. Endocrinology 123 891-897. (doi:10.1210/endo-123-2-891)

Brown RS 2004 Developmental regulation of thyrotropin receptor gene expression in the fetal and newborn thyroid. Endocrinology 145 4058-4061. (doi:10.1210/en.2004-0458)

Calvo R, Obregon MJ, Escobar del Rey F \& Morreale de Escobar G 1992 The rat placenta and the transfer of thyroid hormones from the mother to fetus. Effects of maternal thyroid status. Endocrinology 131 357-365.

Carey LC, Valego NK, Chen K \& Rose JC 2008 Thyroid hormone regulates renocortical COX-2 and PGE2 expression in the late gestation fetal sheep. Reproductive Sciences 15 598-603. (doi:10.1177/ 1933719108316910)

Castello A, Rodriguez-Manzaneque JC, Camps M, Perez-Castillo A, Testar X, Palacin M, Santos A \& Zorzano A 1994 Perinatal hypothyroidism impairs the normal transition of GLUT4 and GLUT1 glucose transporters from fetal to neonatal levels in the heart and brown adipose tissue. Evidence for tissue-specific regulation of GLUT4 expression by thyroid hormones. Journal of Biological Chemistry 269 5905-5912.

Champagne FA 2013 Early environment, glucocorticoid receptors and behavioural epigenetics. Behavioral Neuroscience 127 628-636. (doi:10.1037/a0034186)

Chan L, Miller TF, Yuxin J, Farina C, Chander A, Shaffer TH \& Wolfson MR 1998 Antenatal triiodothyronine improves neonatal pulmonary function in preterm lambs. Journal of the Society for Gynecologic Investigation 5 122-126. (doi:10.1016/S1071-5576(97)00115-9)

Chan S, Kachilele S, McCabe CJ, Tannahill LA, Boelaert K, Gittoes NJ, Visser TJ, Franklyn JA \& Kilby MD 2002 Early expression of thyroid hormone deiodinases and receptors in human fetal cerebral cortex. Brain Research 138 109-116. (doi:10.1016/S0165-3806(02)00459-5)

Chan S, Kachilele S, Hobbs E, Bulmer JN, Boelaert K, McCabe CJ, Driver PM, Bradwell AR, Kester M, Visser TJ et al. 2003 Placental iodothyronine deiodinase expression in normal and growth-restricted human pregnancies. Journal of Clinical Endocrinology and Metabolism $\mathbf{8 8}$ 4488-4495. (doi:10.1210/jc.2003-030228)

Chan SY, Andrews MH, Lingas R, McCabe CJ, Franklyn JA, Kilby MD \& Matthews SG 2005 Maternal nutrient deprivation induces sex-specific changes in thyroid hormone receptor and deiodinase expression in the fetal guinea pig brain. Journal of Physiology 566 467-480. (doi:10.1113/ jphysiol.2005.084673)

Chan SY, Vasilopoulou E \& Kilby MD 2009 The role of the placenta in thyroid hormone delivery to the fetus. Nature Clinical Practice. Endocrinology \& Metabolism 5 45-54. (doi:10.1038/ncpendmet1026)

Chan SY, Martin-Santos A, Loubiere LS, Gonzalez AM, Stieger B, Logan A, McCabe CJ, Franklyn JA \& Kilby MD 2011 The expression of thyroid hormone transporters in the fetal cerebral cortex during early development and in $\mathrm{N}$-tera-2 neurodifferentiation. Journal of Physiology 589 2827-2845. (doi:10.1113/jphysiol.2011.207290)

Chan SY, Hancox LA, Martin-Santos A, Loubiere LS, Walter MN, Gonzalez AM, Cox PM, Logan A, McCabe CJ, Franklyn JA et al. 2014 MCT8 expression in human fetal cerebral cortex is reduced in severe intrauterine growth retardation. Journal of Endocrinology 220 85-95. (doi:10.1530/JOE-13-0400)

Charalambous M \& Hernandez A 2013 Genomic imprinting of the type 3 thyroid hormone deiodinase gene: regulation and developmental implications. Biochimica et Biophysica Acta 1830 3946-3955. (doi:10.1016/j.bbagen.2012.03.015)

Chattergoon NN, Giraud GD \& Thornburg KL 2007 Thyroid hormones inhibit proliferation of fetal cardiac myocytes in vitro. Journal of Endocrinology 192 R1-R8. (doi:10.1677/JOE-06-0114) 
Chattergoon NN, Giraud GD, Louey S, Stork P, Fowden AL \& Thornburg KL $2012 a$ Thyroid hormone drives fetal cardiomyocyte maturation. FASEB Journal 26 397-408. (doi:10.1096/fj.10-179895)

Chattergoon NN, Louey S, Stork P, Giraud GD \& Thornburg KL $2012 b$ Mid-gestation ovine cadiomyocytes are vulnerable to mitotic suppression by thyroid hormone. Reproductive Sciences 19 642-649. (doi:10.1177/1933719111432860)

Chen K, Carey LC, Valego NK, Liu J \& Rose JC 2005 Thyroid hormone modulates renin and ANG II receptor expression in fetal sheep. American Journal of Physiology 289 R1006-R1014.

Chen K, Carey LC, Valego NK \& Rose JC 2007 Thyroid hormone replacement normalises renal renin and angiotensin receptor expression in thyroidectomised fetal sheep. American Journal of Physiology 293 R701-R706.

Chi HC, Chen C-Y, Tsai M-M, Tsai C-Y \& Lin K-H 2013 Molecular functions of thyroid hormones and their clinical significance in liver-related diseases. BioMed Research International 2013 601361. (doi:10.1155/ 2013/601361)

Contempre B, Jauniaux E, Calvo R, Jurkovic D, Campbell S \& Morreale de Escobar G 1993 Detection of thyroid hormones in human embryonic cavities during the first trimester of pregnancy. Journal of Clinical Endocrinology and Metabolism 17 1719-1722.

Crie JS, Wakeland JR, Mayhew BA \& Wildenthal K 1983 Direct anabolic effects of thyroid hormone in isolated mouse heart. American Journal of Physiology 245 C328-C333.

Darras VM, Visser TJ, Berghman LR \& Kuhn ER 1992 Ontogeny of type I and type III deiodinase activities in embryonic and posthatch chicks: relationship with changes in plasma triiodothyronine and growth hormone levels. Comparative Biochemistry and Physiology 103 131-136. (doi:10.1016/0300-9629(92)90252-L)

Darras VM, Kotanen SP, Geris KL, Berghman LR \& Kuhn ER 1996 Plasma thyroid hormone levels and iodothyronine deiodinase activity following an acute glucocorticoid challenge in embryonic compared with posthatch chickens. General and Comparative Endocrinology 104 203-212. (doi:10.1006/gcen.1996.0163)

Das DK, Ayromlooi J, Bandyopadhyay D, Bandyopadhyay S, Neogi A \& Steinberg H 1984 Potentiation of surfactant release in fetal lung by thyroid hormone action. Journal of Applied Physiology $\mathbf{5 6}$ $1621-1626$

Dauncey MJ \& Geers R 1990 Nuclear 3,5,3'-triiodothyronine receptors in skeletal muscle of normal and small-for-gestational-age newborn piglets. Biology of the Neonate 58 291-295. (doi:10.1159/000243281)

De Zegher F, Pernasetti F, Vanhole C, Devlieger H, Van Den Berghe G \& Martial JA 1995 A prismatic case: the prenatal role of thyroid hormone evidenced by fetomaternal Pit-1 deficiency. Journal of Clinical Endocrinology and Metabolism 80 3127-3130.

Edwards JG, Bahl JJ, Flink IL, Cheng SY \& Morkin E 1994 Thyroid hormone influences $\beta$ myosin heavy chain ( $\beta$ MHC) expression. Biochemical and Biophysical Research Communications 199 1482-1488. (doi:10.1006/ bbrc.1994.1398)

Erenberg A, Omori K, Menkes JH, Oh W \& Fisher DA 1974 Growth and development of the thyroidectomized ovine fetus. Pediatric Research $\mathbf{8}$ 783-789. (doi:10.1203/00006450-197409000-00001)

Falcone M, Miyamoto T, Fierro-Renoy F, Macchia E \& DeGroot LJ 1994 Evaluation of the ontogeny of thyroid hormone receptor isotypes in rat brain and liver using an immunohistochemical technique. European Journal of Endocrinology 130 97-106. (doi:10.1530/eje.0.1300097)

Ferreiro B, Bernal J \& Potter BJ 1987 Ontogenesis of thyroid hormone receptor in foetal lambs. Acta Endocrinologica 116 205-210.

Finkelstein DI, Andrianakis P, Luff AR \& Walker D 1991 Effect of thyroidectomy on development of skeletal muscle in fetal sheep. American Journal of Physiology 261 R1300-R1306.

Fisher DA 1997 Fetal thyroid function: diagnosis and management of fetal thyroid disorders. Clinical Obstetrics and Gynecology 40 16-31. (doi:10.1097/00003081-199703000-00005)
Fisher DA \& Polk DH 1989 Development of the thyroid. Baillière's Clinical Endocrinology and Metabolism 3 627-657. (doi:10.1016/S0950$351 \mathrm{X}(89) 80046-1)$

Forbes K \& Westwood M 2008 The IGF axis and placental function: a minireview. Hormone Research 69 129-137. (doi:10.1159/000112585)

Forhead AJ \& Fowden AL 2002 Effects of thyroid hormones on pulmonary and renal angiotensin-converting enzyme concentrations in fetal sheep near term. Journal of Endocrinology 173 143-150. (doi:10.1677/joe.0. 1730143)

Forhead AJ, Li J, Gilmour RS \& Fowden AL 1998 Control of hepatic insulinlike growth factor-II gene expression by thyroid hormones in fetal sheep near term. American Journal of Physiology 275 E149-E156.

Forhead AJ, Gillespie CE \& Fowden AL 2000a Role of cortisol in the ontogenic control of pulmonary and renal angiotensin-converting enzyme in fetal sheep near term. Journal of Physiology 526 409-416. (doi:10.1111/j.1469-7793.2000.00409.x)

Forhead AJ, Li J, Saunders JC, Dauncey MJ, Gilmour RS \& Fowden AL $2000 b$ Control of ovine hepatic growth hormone receptor and insulin-like growth factor-I by thyroid hormones in utero. American Journal of Physiology 278 E1166-E1174.

Forhead AJ, Li J, Gilmour RS, Dauncey MJ \& Fowden AL 2002 Thyroid hormones and the mRNA of the growth hormone receptor and insulinlike growth factor-I in skeletal muscle of fetal sheep. American Journal of Physiology 282 E80-E86.

Forhead AJ, Poore KR, Mapstone J \& Fowden AL 2003 Developmental regulation of hepatic and renal gluconeogenic enzymes by thyroid hormones in fetal sheep during late gestation. Journal of Physiology 548 941-947. (doi:10.1113/jphysiol.2002.035816)

Forhead AJ, Curtis K, Kaptein E, Visser TJ \& Fowden AL 2006 Developmental control of iodothyronine deiodinases by cortisol in the ovine fetus and placenta near term. Endocrinology 147 5988-5994. (doi:10.1210/en.2006-0712)

Forhead AJ, Jellyman JK, Gardner DS, Giussani DA, Kaptein E, Visser TJ \& Fowden AL 2007 Differential effects of maternal dexamethasone treatment on circulating thyroid hormone concentrations and tissue deiodinase activity in the pregnant ewe and fetus. Endocrinology 148 800-805. (doi:10.1210/en.2006-1194)

Forhead AJ, Cutts S, Matthews P \& Fowden AL 2009 Role of thyroid hormones in the developmental control of tissue glycogen in fetal sheep near term. Experimental Physiology 94 1079-1087. (doi:10.1113/ expphysiol.2009.048751)

Fowden AL 2003 The insulin-like growth factors and feto-placental growth. Placenta 24 803-812. (doi:10.1016/S0143-4004(03)00080-8)

Fowden AL \& Forhead AJ 2009 Hormones as epigenetic signals in developmental programming. Experimental Physiology 94 607-625. (doi:10.1113/expphysiol.2008.046359)

Fowden AL \& Forhead AJ 2013 Endocrine interactions in the control of fetal growth. In Maternal and Child Nutrition, vol 74, pp 91-102. Eds J Bhatia, Z Bhutta \& SC Kahlan. Nestlé Nutrition Workshop Series. Freiburg, Germany: Karger. (doi:10.1159/000348417)

Fowden AL \& Silver M 1995 The effects of thyroid hormones on oxygen and glucose metabolism in the sheep fetus during late gestation. Journal of Physiology 482 203-213.

Fowden AL, Li J \& Forhead AJ 1998 Glucocorticoids and the preparation for life after birth: are there long term consequences of the life insurance? Proceedings of the Nutrition Society 57 113-122. (doi:10.1079/ PNS19980017)

Fowden AL, Mapstone J \& Forhead AJ 2001a Regulation of glucogenesis by thyroid hormones in fetal sheep during late gestation. Journal of Endocrinology 170 461-469. (doi:10.1677/joe.0.1700461)

Fowden AL, Ousey JC \& Forhead AJ 2001b Comparative aspects of prepartum maturation; provision of nutrients. Pferdeheilkunde $\mathbf{1 7}$ 653-658.

Fowden AL, Sibley C, Reik W \& Constancia M 2006 Imprinted genes, placental development and fetal growth. Hormone Research $\mathbf{6 5}$ (Suppl 3) 49-57. 
Friesema ECH, Jansen J \& Visser TJ 2005 Thyroid hormone transporters. Biochemical Society Transactions 33 228-232. (doi:10.1042/BST0330228)

Gilbert WM, Eby-Wilkens E, Plopper C, Whitsett JA \& Tarantal AF 2001 Fetal monkey surfactants after intra-amniotic or maternal administration of betamethasone and thyroid hormones. Obstetrics and Gynecology 98 466-470. (doi:10.1016/S0029-7844(01)01417-X)

Gnanalingham MG, Mostyn A, Forhead AJ, Fowden AL, Symonds ME \& Stephenson T 2005 Increased uncoupling protein-2 mRNA during late gestation is dependent on plasma cortisol and tri-iodothyronine. Journal of Physiology 567 283-292. (doi:10.1113/jphysiol.2005.091223)

Guerra C, Porras A, Roncero C, Benito M \& Fernandez M 1994 Triiodothyronine induces expression of the uncoupling protein in long term fetal rat brown adipocyte primary cultures: role of nuclear thyroid hormone receptor expression. Endocrinology 134 1067-1074.

Hall JA, Robich S, Christoffolete MA, Simovic G, Correa-Medina M, Patti ME $\&$ Bianco AC 2010 Absence of thyroid hormone activation during development underlies a permanent defect in adaptive thermogenesis. Endocrinology 151 4573-4582. (doi:10.1210/en.2010-0511)

Hausman GJ 1992 The influence of thyroxine on the differentiation of adipose tissue and skin during fetal development. Pediatric Research 32 204-211. (doi:10.1203/00006450-199208000-00016)

Hausman DB, Hausman GJ \& Martin RJ 1996 Endocrine regulation of fetal adipose tissue metabolism in the pig: ontogeny of thyroxine influence. Biology of the Neonate 70 41-51. (doi:10.1159/000244347)

Hernandez A, Fiering S, Matinez E, Galton VA \& St Germain D 2002 The gene locus encoding iodothyronine deiodinase type 3 (Dio3) is imprinted in the fetus and expresses antisense transcripts. Endocrinology 143 4483-4486. (doi:10.1210/en.2002-220800)

Hernandez A, Matinez E, Fiering S, Galton VA \& St Germain D 2006 Type 3 deiodinase is critical for the maturation and function of the thyroid axis. Journal of Clinical Investigation 116 476-484. (doi:10.1172/ JCI26240)

Herpin P, Berthin D, Duchamp C, Dauncey MJ \& Le Dividich J 1996 Effect of thyroid status in the perinatal period on oxidative capacities and mitochondrial respiration in porcine liver and skeletal muscle. Reproduction, Fertility, and Development 8 147-155. (doi:10.1071/ RD9960147)

Heuer H \& Visser TJ 2013 The pathophysiological consequences of thyroid hormone transporter deficiencies: insights from mouse models. Biochimica et Biophysica Acta 1830 3974-3978. (doi:10.1016/j.bbagen. 2012.04.009)

Hillman NH, Kallaour SG \& Jobe A 2012 Physiology of transition from intrauterine to extrauterine life. Clinics in Perinatology 39 769-783. (doi:10.1016/j.clp.2012.09.009)

Hopkins PS \& Thorburn GD 1972 The effects of foetal thyroidectomy on the development of the ovine foetus. Journal of Endocrinology 54 55-66. (doi:10.1677/joe.0.0540055)

Hopkins PS, Wallace AL \& Thorburn GD 1975 Thyrotrophin concentrations in the plasma of cattle, sheep and foetal lambs as measured by radioimmunoassay. Journal of Endocrinology 64 271-387. (doi:10.1677/ joe.0.0640371)

Horn S \& Heuer H 2010 Thyroid hormone action during brain development: more questions than answers. Molecular and Cellular Endocrinology 315 19-26. (doi:10.1016/j.mce.2009.09.008)

Jansen J, Friesema ECH, Milici C \& Visser TJ 2005 Thyroid hormone transporters in health and disease. Thyroid 15 757-768. (doi:10.1089/ thy.2005.15.757)

Jost A 1979 Fetal hormones and fetal growth. Contributions to Gynecology and Obstetrics 5 1-20.

Kester MH, Kaptein E, Van Dijk CH, Roest TJ, Tibboel D, Coughtrie MW \& Visser TJ 2002 Characterization of iodothyronine sulfatase activities in human and rat liver and placenta. Endocrinology 143 814-819. (doi:10.1210/endo.143.3.8686)

Kilby MD, Gittoes VN, Somerset DA, Clark PM \& Franklyn JA 1998 Circulating thyroid hormone concentrations and placental thyroid hormone receptor expression in normal human pregnancy and pregnancy complicated by intrauterine growth restriction (IUGR). Journal of Clinical Endocrinology and Metabolism 83 2964-2971. (doi:10.1210/jcem.83.8.5002)

Kilby MD, Gittoes N, McCabe CJ, Verhaeg J \& Franklyn JA 2000 Expression of thyroid receptor isoforms in the human fetal central nervous system and the effects of intrauterine growth restriction. Clinical Endocrinology 53 469-477. (doi:10.1046/j.1365-2265.2000.01074.x)

Klein AH, Reviczky A, Padbury JF \& Fisher DA 1983 Effects of changes in thyroid status on tissue respiration in fetal and newborn sheep. American Journal of Physiology 244 E603-E606.

Klein AH, Reviczky A \& Padbury JF 1984 Thyroid hormone augment catecholamine-stimulated brown adipose tissue thermogenesis in the ovine fetus. Endocrinology 114 1065-1069. (doi:10.1210/ endo-114-4-1065)

Koopdonk-Kool JM, de Vijlder JJ, Veenboer GJ, Ris-Stalpers C, Kok JH, Vulsma T, Boer K \& Visser TJ 1996 Type II and type III deiodinase activity in human placenta as a function of gestational age. Journal of Clinical Endocrinology and Metabolism 81 2154-2158.

Kruger M, Sachse C, Zimmermann WH, Eshenhagen T, Klede S \& Linke WA 2008 Thyroid hormone regulates developmental titin isoform transitions via the phosphatidylinositol-3-kinase/AKT pathway. Circulation Research 102 439-447. (doi:10.1161/CIRCRESAHA.107.162719)

Landers KA, Mortimer RH \& Richard K 2013 Transthyretin and the human placenta. Placenta 34 513-517. (doi:10.1016/j.placenta. 2013.04.013)

Lanham SA, Fowden AL, Roberts C, Cooper C, Oreffo RO \& Forhead AJ 2011 Effects of hypothyroidism on the structure and mechanical properties of bone in the ovine fetus. Journal of Endocrinology 210 189-198. (doi:10.1530/JOE-11-0138)

Latimer AM, Hausman GJ, McCusker RH \& Buonomo FC 1993 The effects of thyroxine on serum and tissue concentrations on insulin-like growth factors (IGF-I and IGF-II) and IGF binding proteins in the fetal pig. Endocrinology 133 1312-1319.

Li H, Patel J, Mortimer RH \& Richard K 2012 Ontogenic changes in human placental sodium iodide symporter expression. Placenta 33 946-948. (doi:10.1016/j.placenta.2012.08.002)

Liu J, Chen K, Valego NK, Carey LC \& Rose JC 2005 Ontogeny and effects of thyroid hormone on $\beta$-1-adrenergic receptor mRNA expression in ovine fetal kidney cortex. Journal of the Society for Gynecologic Investigation 12 563-569. (doi:10.1016/j.jsgi.2005.08.007)

Lorijn RHW \& Longo LD 1980 Clinical and physiological implications of increased fetal oxygen consumption. American Journal of Obstetrics and Gynecology 136 451-457.

Lorijn RHW, Nelson JC \& Longo LD 1980 Induced fetal hyperthyroidism: cardiac output and oxygen consumption. American Journal of Physiology 239 H302-H307.

Loubiere LS, Vasilopoulou E, Bulmer JN, Taylor PM, Stieger B, Verrey F, McCabe CJ, Franklyn JA, Kilby MD \& Chan SY 2010 Expression of thyroid hormone transporters in the human placenta and changes associated with intrauterine growth retardation. Placenta 31 295-304. (doi:10.1016/j.placenta.2010.01.013)

Loubiere LS, Vasilopoulou E, Glazier JD, Taylor PM, Franklyn JA, Kilby MD \& Chan SY 2012 Expression and function of thyroid hormone transporters in the microvillous plasma membrane of human term placental syncytiotrophoblast. Endocrinology 153 6126-6135. (doi:10.1210/en.2012-1753)

Mai W, Janier MF, Allioli N, Quignodon L, Chuzel T, Flamart F \& Samarut J 2004 Thyroid hormone receptor $\alpha$ is a molecular switch of cardiac function between fetal and postnatal life. PNAS 101 10332-10337. (doi:10.1073/pnas.0401843101)

Medina MC, Molina J, Gadea Y, Fachado A, Murillo M, Simovic G, Pileggi A, Hernandez A, Edlind H \& Bianco AC 2011 The thyroid hormoneinactivating type III deiodinase is expressed in mouse and human $\beta$ cells and its targeted inactivation impairs insulin secretion. Endocrinology 152 3717-3727. (doi:10.1210/en.2011-1210) http://joe.endocrinology-journals.org DOI: $10.1530 / J O E-14-0025$
(C) 2014 Society for Endocrinology Printed in Great Britain 
Mendelson CR \& Boggaram V 1991 Hormonal control of the surfactant system in fetal lung. Annual Review of Physiology 53 415-440. (doi:10.1146/annurev.ph.53.030191.002215)

Mesiano S, Young IR, Baxter RC, Hintz RL, Browne CA \& Thorburn GD 1987 Effect of hypophysectomy with and without thyroxine replacement on growth and circulating concentrations of insulin-like growth factors I and II in the fetal lamb. Endocrinology 120 1821-1830. (doi:10.1210/endo-120-5-1821)

Metz LD, Seidler FJ, McCook EC \& Slotkin TA 1996 Cardiac $\alpha$-adrenergic receptor expression is regulated by thyroid hormones during a critical developmental period. Journal of Molecular and Cellular Cardiology $\mathbf{2 8}$ 1033-1044. (doi:10.1006/jmcc.1996.0096)

Morreale de Escobar G, Calvo R, Obregon MJ \& Escobar Del Rey F 1990 Contribution of maternal thyroxine to fetal thyroxine pools in normal rats near term. Endocrinology 126 2765-2767. (doi:10.1210/endo-126-5-2765)

Mostyn A, Pearce S, Budge H, Elmes M, Forhead AJ, Fowden AL, Stephenson T \& Symonds ME 2003 Influence of cortisol on adipose tissue development in the fetal sheep during late gestation. Journal of Endocrinology 176 23-30. (doi:10.1677/joe.0.1760023)

Nagasawa T, Suzuki S, Takeda T \& DeGroot LJ 1997 Thyroid hormone receptor $\beta 1$ expression in developing mouse limbs and face. Endocrinology 138 1276-1281.

Ng L, Lybarsky A, Nikonov SS, Ma M, Srinivas M, Kefas B, St Germain DL, Hernandez A, Pugh EN \& Forrest D 2010 Type 3 deiodinase, a thyroidhormone-inactivating enzyme, controls survival and maturation of cone photoreceptors. Journal of Neuroscience 30 3347-3357. (doi:10.1523/JNEUROSCI.5267-09.2010)

Obregon MJ, Calvo RM, del Ray FE \& De Escobar GM 2007 Ontogenesis of thyroid function and interactions with maternal function. In Thyroid gland development and function, Vol 10, pp 86-98. Eds G Van Vliet \& M Polak. Endocrine Development. Basal, Switzerland: Karger. (doi:10.1159/000106821)

O'Connor DM, Blanche D, Hoggard N, Brookes E, Wooding FB, Fowden AL $\&$ Forhead AJ 2007 Developmental control of plasma leptin and adipose leptin mRNA in the ovine fetus during late gestation: role of glucocorticoids and thyroid hormones. Endocrinology 148 3750-3757. (doi:10.1210/en.2007-0310)

Olver RE, Schneeberger EE \& Walters DV 1981 Epithelial solute permeability, ion transport and tight junction morphology in the developing lung of the fetal lamb. Journal of Physiology 315 395-412.

Patel J, Landers K, Li H, Mortimer RH \& Richard K 2011 Thyroid hormones and fetal neurological development. Journal of Endocrinology 209 1-8. (doi:10.1530/JOE-10-0444)

Pereira DN \& Procianoy RS 2003 Effect of perinatal asphyxia on thyroidstimulating hormone and thyroid hormone levels. Acta Paediatrica 92 339-345. (doi:10.1111/j.1651-2227.2003.tb00556.x)

Perez-Castillo A, Bernal J, Ferreiro B \& Pans T 1985 The early ontogenesis of thyroid hormone receptor in the rat fetus. Endocrinology 117 2457-2461. (doi:10.1210/endo-117-6-2457)

Piosik PA, van Groenigen M, van Doorn J, Baas F \& Vijlder JJ 1997 Effects of maternal thyroid status on thyroid hormones and growth in congenitally hypothyroid goat fetuses during the second half of gestation. Endocrinology 138 5-11.

Polk DH 1995 Thyroid hormone metabolism during development. Reproduction, Fertility, and Development 7 469-477. (doi:10.1071/ RD9950469)

Polk DH, Callegari CC, Newnham J, Padbury JF, Reviczky A, Fisher DA \& Klein AH 1987 Effect of fetal thyroidectomy on newborn thermogenesis in lambs. Pediatric Research 21 453-457. (doi:10.1203/00006450198705000-00006)

Polk DH, Wu S-Y, Wright C, Reviczky AL \& Fisher DA 1988 Ontogeny of thyroid hormone effect on tissue $5^{\prime}$-monodeiodinase activity in fetal sheep. American Journal of Physiology 254 E337-E341.

Polk D, Cheromcha D, Reviczky A \& Fisher DA 1989 Nuclear thyroid hormone receptors: ontogeny and thyroid hormone effects in sheep. American Journal of Physiology 256 E543-E549.
Polk DH, Reviczky A, Lam RW \& Fisher DA 1991 Thyrotropin-releasing hormone in the ovine fetus: ontogeny and effect of thyroid hormone. American Journal of Physiology 260 E53-E58.

Power GG, Gunn TR, Johnston BM, Nichols G \& Gluckman PD 1989 Umbilical cord occlusion but not increased plasma $T_{3}$ or norepinephrine stimulate brown adipose tissue thermogenesis in the fetal sheep. Journal of Developmental Physiology 11 171-177.

Puig-Domingo M \& Vila L 2013 The implications of iodine and its supplementation during pregnancy in fetal brain development. Current Clinical Pharmacology 8 97-109. (doi:10.2174/1574884711308020002)

Rae MT, Rhind SM, Kyle CE, Miller DW \& Brooks AN 2002 Maternal undernutrition alters triiodothyronine concentrations and pituitary response to GnRH in fetal sheep. Journal of Endocrinology 173 449-455. (doi:10.1677/joe.0.1730449)

Rakover Y, Weiner E, Mosh N \& Shalev E 1999 Fetal pituitary negative feedback at early gestational age. Clinical Endocrinology 50 809-814. (doi:10.1046/j.1365-2265.1999.00767.x)

Ramminger SJ, Inglis SK, Olver RE \& Wilson SM 2002 Hormonal modulation of $\mathrm{Na}(+)$ transport in rat fetal distal lung epithelial cells. Journal of Physiology 544 567-577. (doi:10.1113/jphysiol.2002.022459)

Richard K, Hume R, Kaptein E, Stanley EL, Visser TJ \& Coughtrie MW 2001 Sulfation of thyroid hormone and dopamine during human development: ontogeny of phenol sulfotransferases and arylsulfatase in liver, lung, and brain. Journal of Clinical Endocrinology and Metabolism 86 2734-2742.

Richards GE, Morrow DA, Thominet JL, Silverman BL \& Gluckman PD 1993 The effect of thyroidectomy on growth hormone regulation in the ovine fetus. Journal of Developmental Physiology 19 165-169.

Romaguera J, Ramirez M \& Adamsons K 1993 Intra-amniotic thyroxine to accelerate fetal maturation. Seminars in Perinatology 17 260-266.

Sack J, Kaiserman I \& Siebner R 1993 Maternal-fetal $T_{4}$ transfer does not suffice to prevent the effects of in utero hypothyroidism. Hormone Research 39 1-7. (doi:10.1159/000182686)

Santisteban P 2013 Development and anatomy of the hypothalamicpituitary-thyroid axis. In Werner \& Ingbar's The Thyroid: A fundamental and Clinical Text, 10th edn, pp 4-23. Eds LE Braverman \& DS Cooper. Lippincott, Williams \& Wilkins.

Schermer SJ, Bird JA, Lomax MA, Shepherd DA \& Symonds ME 1996 Effect of fetal thyroidectomy on brown adipose tissue and thermoregulation in newborn lambs. Reproduction, Fertility, and Development 8 995-1002. (doi:10.1071/RD9960995)

Schroder HJ, Huneke B, Klug A, Stegner H, Carstensen M \& Leichtweiss HP 1987 Fetal sheep temperatures in utero during cooling and application of triiodothyronine, norepinephrine, propranolol and suxamethonium. Pflügers Archiv 410 376-384. (doi:10.1007/BF00586514)

Segar JL, Volk KA, Lipman MH \& Scholz TD 2013 Thyroid hormone is required for growth adaptation to pressure load in the ovine fetal heart. Experimental Physiology 98 722-733. (doi:10.1113/expphysiol.2012. 069435)

Sferruzzi-Perri AN, Vaughan OR, Forhead AJ \& Fowden AL 2013 Hormonal and nutritional drivers of intrauterine growth. Current Opinion in Clinical Nutrition and Metabolic Care 16 298-309. (doi:10.1097/ MCO.0b013e32835e3643)

Shields BM, Knight BA, Hill A, Hattersley AT \& Vaidya B 2011 Fetal thyroid hormone level at birth is associated with fetal growth. Journal of Clinical Endocrinology and Metabolism 96 E934-E938. (doi:10.1210/ jc.2010-2814)

Silva JE 2011 Physiological importance and control of non-shivering facultative thermogenesis. Frontiers in Bioscience 3 352-371. (doi:10.2741/s156)

Spencer GS, Hallett KG, Beerman U \& Macdonald AA 1989 Changes in the levels of growth hormone, insulin, cortisol, thyroxine and somatomedin-C/IGF-I with increasing gestational age in the fetal pig and the effects of thyroidectomy in utero. Comparative Biochemistry and Physiology. A, Comparative Physiology 93 467-472. (doi:10.1016/03009629(89)90068-6) 
Stenzel D \& Huttner WB 2013 Role of maternal thyroid hormones in the developing neocortex and during human evolution. Frontiers in Neuroanatomy 7 19. (doi:10.3389/fnana.2013.00019)

Symonds ME, Mostyn A, Pearce S, Budge H \& Stephenson T 2003 Endocrine and nutritional regulation of fetal adipose tissue development. Journal of Endocrinology 179 293-299. (doi:10.1677/joe.0.1790293)

Thorburn GD \& Hopkins PS 1973 Thyroid function in the foetal lamb. In Foetal and Neonatal Physiology, pp 488-507. Eds RS Comline, KW Cross, GS Dawes \& PW Nathanielsz. Cambrige University Press.

Thornburg K, Jonker S, O’Tierney P, Chattergoon N, Louey S, Faber J \& Giraud G 2011 Regulation of the cardiomyocyte population in the developing heart. Progress in Biophysics and Molecular Biology 106 289-299. (doi:10.1016/j.pbiomolbio.2010.11.010)

Thorpe-Beeston JG, Nicolaides KH, Felton CV, Butler J \& McGregor AM $1991 a$ Maturation of the secretion of thyroid hormone and thyroidstimulating hormone in the fetus. New England Journal of Medicine 324 532-536. (doi:10.1056/NEJM199102213240805)

Thorpe-Beeston JG, Nicolaides KH, Snijders RJ, Felton CV \& McGregor AM $1991 b$ Thyroid function in small for gestational age fetuses. Obstetrics and Gynecology 77 701-706.

Torday JS \& Dow KE 1984 Synergistic effect of triiodothyronine and dexamethasone on male and female fetal rat lung surfactant synthesis. Developmental Pharmacology and Therapeutics 7 133-139.

Tsai C-E, Lin S-P, Ito M, Takagi N, Takada S \& Ferguson-Smith AC 2002 Genomic imprinting contributes to thyroid hormone metabolism in the mouse embryo. Current Biology 12 1221-1226. (doi:10.1016/ S0960-9822(02)00951-X)

van Tuyl M, Blommaart PE, Boer PAJ, Wert SE, Ruijter JM, Islam S, Schnitzer J, Ellison AR, Tibboel D, Moorman AF et al. 2004 Prenatal exposure to thyroid hormones is necessary for normal postnatal development of murine heart and lungs. Developmental Biology 272 103-117. (doi:10.1016/j.ydbio.2004.03.042)

Ueta CB, Oskouei BN, Olivares EL, Pinto JR, Correa MM, Simovic G, Simonides WS, Hare JM \& Bianco AC 2012 Absence of myocardial thyroid hormone inactivating deiodinase results in restrictive cardiomyopathy in mice. Molecular Endocrinology 26 809-818. (doi:10.1210/ me.2011-1325)

Vega-Nunez E, Menendez-Hurtado A, Garesse R, Santos A \& Perez-Castillo A 1995 Thyroid hormones-regulated brain mitochondrial genes revealed by differential cDNA cloning. Journal of Clinical Investigation 96 893-899. (doi:10.1172/JCI118136)
Visser WE, Friesema ECH, Jansen J \& Visser TJ 2008 Thyroid hormone transport in and out of cells. Trends in Endocrinology and Metabolism 19 50-56. (doi:10.1016/j.tem.2007.11.003)

Vulsma T, Gins MH \& de Vijlder JJ 1989 Maternal-fetal transfer of thyroxine in congenital hypothyroidism due to total organification defect or thyroid agenesis. New England Journal of Medicine 321 13-16. (doi:10.1056/NEJM198907063210103)

Walker DW \& Schuijers JA 1989 Effect of thyroidectomy on cardiovascular responses to hypoxia and tyramine infusion in fetal sheep. Journal of Developmental Physiology 12 337-345.

Warburton D, Parton L, Buckley S, Cosico L, Enns G \& Saluna T 1988 Combined effects of corticosteroid, thyroid hormones and $\beta$-agonists on surfactant, pulmonary mechanics and $\beta$-receptor binding in fetal lamb lung. Pediatric Research 24 166-170. (doi:10.1203/00006450198808000-00005)

White P, Burton KA, Fowden AL \& Dauncey MJ 2001 Developmental expression analysis of thyroid hormone receptor isoforms reveals new insights into their essential functions in cardiac and skeletal muscles. FASEB Journal 15 1367-1376. (doi:10.1096/fj.00-0725com)

Wilson SM, Olver RE \& Walters DV 2007 Developmental regulation of luminal lung liquid and electrolyte transport. Respiratory Physiology \& Neurobiology 159 247-255. (doi:10.1016/j.resp.2007.10.004)

Wrutniak C \& Cabello G 1983 Changes in the concentration of thyroxine in the plasma of rat fetuses during late gestation: influence of ligation of the maternal uterine vein and artery. Journal of Endocrinology 99 233-238. (doi:10.1677/joe.0.0990233)

Wrutniak C, Rochard P, Casas F, Fraysse A, Charrier J \& Cabello G 1998 Physiological importance of the $\mathrm{T}_{3}$ mitochondrial pathway. Annals of the New York Academy of Sciences 839 93-100. (doi:10.1111/j.1749-6632. 1998.tb10738.x)

Wu S, Polk D, Wong S, Reviczky A, Vu R \& Fisher DA 1992 Thyroxine sulphate is a major thyroid hormone metabolite and a potential intermediate in the monodeiodination pathways in fetal sheep. Endocrinology 131 1751-1756.

Wu SY, Polk DH, Huang WS, Reviczky A, Wang K \& Fisher DA 1993 Sulfate conjugates of iodothyronines in developing sheep: effect of fetal hypothyroidism. American Journal of Physiology 265 E115-E120.

Yasuda T, Ohnishi H, Wataki K, Minagawa M, Minamitani K \& Niimi H 1999 Outcome of a baby born of a mother with acquired juvenile hypothyroidism having undetectable thyroid hormone concentrations. Journal of Clinical Endocrinology and Metabolism 84 2630-2632.

Received in final form 26 February 2014

Accepted 18 March 2014

Accepted Preprint published online 19 March 2014 http://joe.endocrinology-journals.org DOI: $10.1530 / J O E-14-0025$ (c) 2014 Society for Endocrinology Printed in Great Britain
Published by Bioscientifica Ltd 